\title{
Enhancement of Existing Geothermal Resource Utilization by Cascading to Intensive Aquaculture
}

\author{
Prepared For \\ U.S. Department of Energy \\ Idaho Operations Office \\ 785 DOE Place \\ Idaho Falls, Idaho 83401 \\ Contract No. DE-FC07-93ID13203

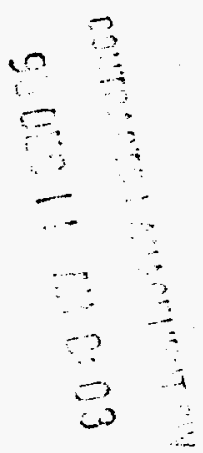

\section{Prepared By}

Dr. Walter H. Zachritz II, Mr. Ronald Polka, and

Dr. Rudi Schoenmackers

Southwest Technology Development Institute

Division of Environmental Systems

College of Engineering

New Mexico State University

P.O. Box 30001/Dept. 3SOLAR

Las Cruces, New Mexico 88003-8001

December 4, 1995

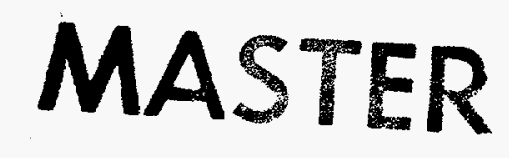




\section{Disclaimer Statement}

This report was prepared with the support of the U.S. Department of Energy (DOE Grant No. DE-FC07-93ID13203). However, any opinions, findings, conclusions, or recommendations expressed herein are those of the authors and do not necessarily reflect the views of DOE.

\section{DISCLAIMER}

This report was prepared as an account of work sponsored by an agency of the United States Government. Neither the United States Government nor any agency thereof, nor any of their employees, makes any warranty, express or implied, or assumes any legal liability or responsibility for the accuracy, completeness, or usefulness of any information, apparatus, product, or process disclosed, or represents that its use would not infringe privately owned rights. Reference herein to any specific commercial product, process, or service by trade name, trademark, manufacturer, or otherwise does not necessarily constitute or imply its endorsement, recommendation, or favoring by the United States Government or any agency thereof. The views and opinions of authors expressed herein do not necessarily state or reflect those of the United States Government or any agency thereof. 


\section{DISCLAMMER}

Portions of this document may be illegible in electronic image products. Images are produced from the best available original document. 


\section{Acknowledgments}

The authors would like to acknowledge the assistance of Ms. Marty López for proofing and final formatting of the manuscript and Suzanne Molina for preparation of tables and typing. The authors would also like to thank Ms. Carol Fischer for comments and corrections. The authors would also like to thank Hugh Bailey, Octavio Holguin, Sean Lanier, Srinivas Rao, Ted Richardson, and Eric Schroeder for their help in construction of the facility. Additional thanks are extended to Big Chief Stone, Inc. of Las Cruces, New Mexico, for their donation of lava rock for use as media in Constructed Wetlands. And to Miss-Ark Fisheries, Inc. of Starkville, Mississippi, for providing fingerlings for the project. The authors also acknowledge the technical input and advise of Mr. Kevin Fitzsimmons of the University of Arizona. 


\section{Table of Contents}

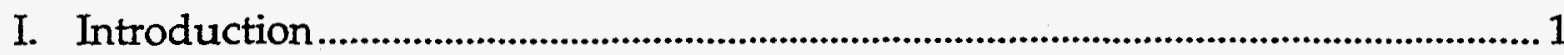

II. New Mexico State University (NMSU) Geothermal Facilities................................... 3

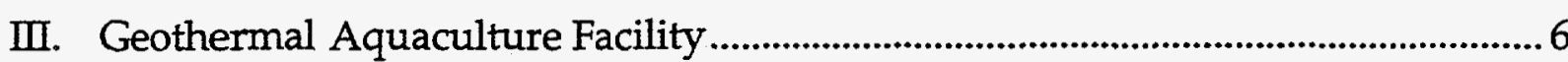

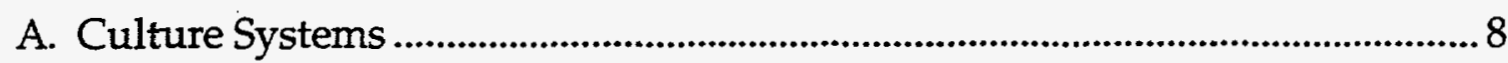

B. Temperature Control Systems ……….............................................................. 16

C. Data Acquisition and Control System ……...................................................... 19

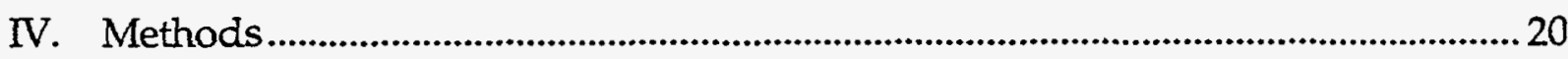

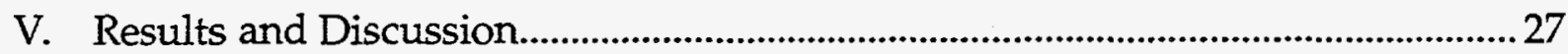

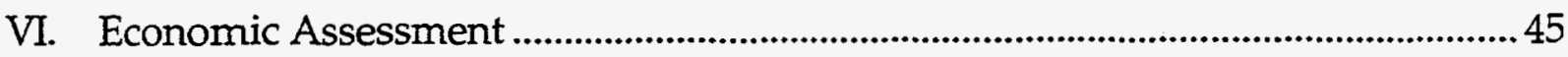

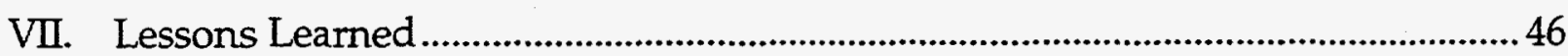

VIII. Summary

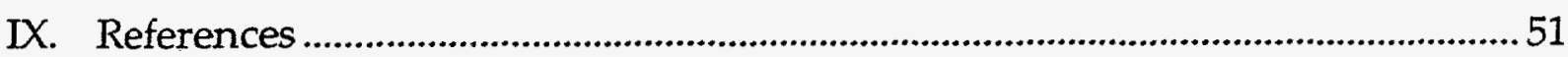




\section{List of Figures}

Figure

Page

1. Layout of the Geothermal Greenhouse Facility at New Mexico State University.

2. Process Flow Diagram for the Geothermal-Based Aquaculture Production System

3. Piping Diagram of the Floating Bead Filter for Culture System I.

4. Piping Diagram of the Artificial Wetlands Filter (AWF) System for Culture System II.

5. Layout of the Heat Exchanger Unit for Indirect Temperature Control 18

6. Cascaded Geothermal Fluid Temperatures (March 14, 1995) .29

7. Culture Water Temperatures for System I (March 14, 1995) 31

8. Culture Water Temperatures for System II (March 14, 1995) .33

9. Culture System I Energy Balance (February-March 1995) .35

10. Culture System II Energy Balance (February-March 1995) 37

11. Geothermal Use by Application (February-March 1995) 39

12. Water Balance Data for Culture System I (February-March 1995) 42

13. Water Balance Data for Culture System II (February-March 1995) 43

\section{List of Tables}

Table Page

1. Geothermal Energy Consumption During February-March 1995 40 


\section{Introduction}

Aquaculture, the farming and husbandry of freshwater and marine organisms, is the newest and fastest growing U.S. agricultural sector. Nationwide, the aquaculture industry is developing at nearly 20 percent per year in commodity sectors that include finfish, shrimp, crawfish, clams, and tropical fish. Domestic catfish production has increased dramatically between 1985 and 1993 with 1993 production of 500 million lbs giving a total pre-processing value to the industry of over $\$ 365$ million (USDA 1994). The tropical fish industry in the U.S. is valued at over $\$ 500$ million in annual retail sales and over $\$ 4$ billion worldwide (Winfree, 1989). Trout, produced mainly in Idaho's Snake River Valley, has an annual production of over 36 million pounds (Brannon, 1987). U.S. consumption of imported and domestically grown Tilapia in 1994 topped 60 million pounds, surpassing the consumption of trout (ATA, 1995). Coupling these trends with a changing pattern of consumer demand from beef to chicken and fish presents a very encouraging potential for aquaculture production.

In New Mexico, low winter temperatures (Balm et al., 1987) and limited freshwater sources (Lansford et al., 1987) narrow culture production possibilities; however, it has long been recognized that the state has abundant supplies of both saline and geothermal ground waters. As much as two-thirds of the state is underlain by saline water at varying depths and low temperature geothermal waters $\left(90-200^{\circ} \mathrm{F}\right)$ are abundant north to south along the Rio Grande Rift and in the southwestern part of the state. Numerous surface hot springs are found in some of these regions, but generally the depth of geothermal waters ranges from less than 20 feet to several thousand feet. Saline water around the Roswell, New Mexico, area has been shown to be adaptable for 
growing algae, but low winter time water temperatures limited annual production to only six months (Weissman, 1992). Maintaining ideal growing temperatures throughout the winter months is critical to developing an aquaculture industry in New Mexico. We know that geothermal and saline aquifers interface, but almost nothing is known about the actual distribution of temperature and salinity for these regions. For aquaculture, ground water temperatures of greater than $80^{\circ} \mathrm{F}$ and salinities from 1,000 $\mathrm{mg} / \mathrm{l}$ to over $12,000 \mathrm{mg} / \mathrm{l}$ as total dissolved solids would be suitable for culturing a variety of high value species. Identification of the critical regions where these waters occur at appropriate culture temperatures could provide significant areas for aquaculture development.

The use of geothermal fluids for direct use heating has applications for many sites throughout the world including China and Greece (Zhang and Liu 1988; Bin et al., 1988; Popovski, 1989). Low temperature geothermal sites $\left(<200^{\circ} \mathrm{F}\right)$ are being developed in many parts of the U.S. and around the state for greenhouse space heating, floriculture production, and other potential uses (Whittier et al., 1991). New Mexico leads the nation in geothermally-heated greenhouse space with over one million square feet of production (Schoenmackers, 1990). Because the cost of well drilling and piping for these sites is already expended, there is tremendous opportunity for accelerated development for aquaculture production at these sites. These waters can be used as both the culture media and directly or indirectly for system temperature control for high density culture systems. Geothermal water has been used to culture a variety of aquaculture species in many parts of the western U.S. including freshwater prawns, Gambusia, and catfish (Hayes and Johnson, 1983; Cheyne, 1982; Smith, 1984; WRAC, 
1989). Wastewaters discharged from such a facility can be reused for value-added production of crops such as lettuce, water chestnuts, herbs, water lilies, afghan pines, native ornamentals, and many others (Boyle et al., 1993; Berghage et al., 1995). This type of sustainable, integrated system would provide multiple use of the water, optimum energy efficiency, and eliminate wastewater discharge to the environment. Coupling New Mexico's abundant sunshine with the use of low-temperature geothermal waters can provide the kind of constant system temperature for needed highly accelerated aquaculture production. This can provide New Mexico with a competitive edge for entering the high-value seafood marketplace.

The purpose of this project was to demonstrate the achievable energy savings and value enhancement of the byproduct geothermal energy by cascading fluids for the production of commercial aquaculture species. Specifically the project involved evaluating the heating systems performance in terms of heating budget for the geothermal assist, determine the total quantity of water used for culture and heating, amount of geothermal byproduct heat extracted, and ability of the system to maintain culture water temperatures during critical heating periods of the year. In addition, an analysis was conducted to determine the compatibility of this new system with existing greenhouse heating requirements.

\section{New Mexico State University (NMSU) Geothermal Facilities}

The New Mexico State University (NMSU) Aquaculture Production Facility is located adjacent to the NMSU Geothermal Greenhouse Research Facility about one mile east of the main NMSU campus. The heat source for the facility and the NMSU campus 


\section{)}

is the geothermal production well PG4. The well is 1,014 feet deep and is capable of producing a sustained yield in excess of 2,000 gallons per minute at a wellhead temperature of $146^{\circ} \mathrm{F}$. Currently, a $30-\mathrm{HP}$ Grundfos submersible pump suspended at 434 feet provides a flow of 140 gallons per minute (gpm).

About 82 percent of the flow is diverted to the NMSU campus for district heating. The NMSU campus heating system uses a heat exchanger with a recirculating hydronic loop to provide space heating to over 30 buildings and the natatorium on the NMSU campus. Spent geothermal fluid from this use is reinjected to the geothermal aquifer via an injection well located a half mile from the production well. This system has been operating successfully since about 1993. In the event of a pump or well failure, geothermal water is available from NMSU production wells PG1 and PG3. The production well PG4 has been continuously operational since 1986.

About 18 percent of the geothermal water is diverted to heating incubator greenhouses at the Southwest Technology Development Institute (SWTDI) Geothermal Greenhouse Facility. The basic layout for this system is shown in Figure 1. The greenhouse facility uses geothermal water to heat two floriculture production greenhouses with about $12,000 \mathrm{ft}^{2}$ of production area. SWTDI has operated these incubator space greenhouses which are leased to private clients since 1986. Six business operations have directly resulted from the occupancy of this facility.

The geothermal water energy is used two ways: for indirect space heating through a hydronic loop with water to air heat exchangers and directly in a bench top heating system. A plate and frame heat exchanger transfers heat from the geothermal fluid to a freshwater hydronic loop that is pumped to the adjacent incubator greenhouses. Using 


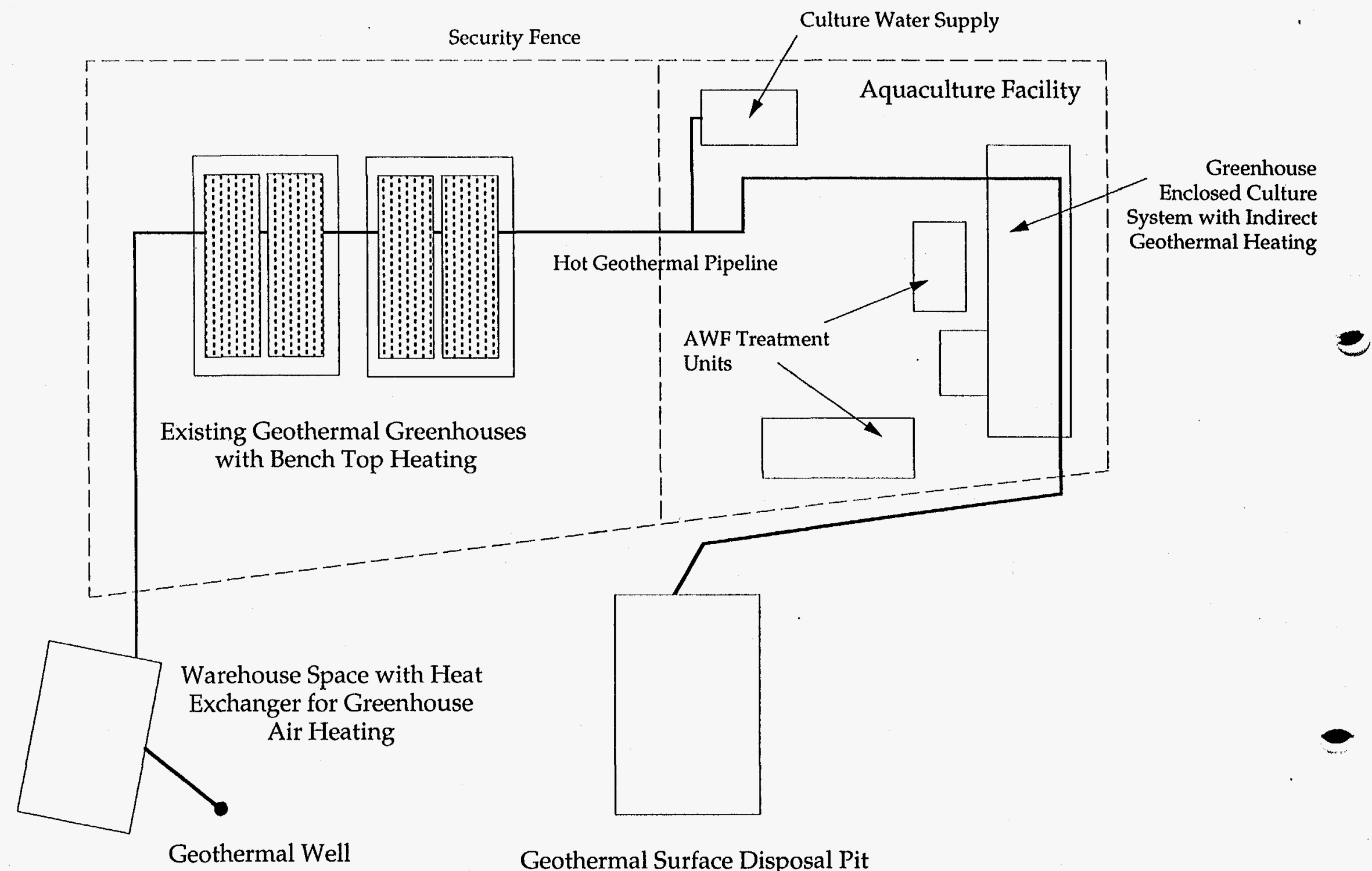

Figure 1. Layout of the Geothermal Greenhouse Facility at New Mexico State University. 
a computer-based control program and interface, set points are used to control air temperatures in the greenhouses. Heating is provided by the geothermal systems and cooling is provided by a standard pad and fan arrangement with a three stage setting to reduce energy consumption. Operation of the space air heating system lowers the geothermal fluid temperature 10 to $25^{\circ} \mathrm{F}$, depending on the heating load of the greenhouses. The bench top heating system is used to provide soil heating for horticulture cultivation and production. The bench top systems operate through a series of about $50,000 \mathrm{ft}$ of $5 / 32$ inch ID rubber tubing tapped directly into the hot geothermal feed piping via motorized ball valves. When the bench top systems are operating, the geothermal fluid is cooled an additional 15 to $30^{\circ} \mathrm{F}$.

After this final use in the incubator greenhouses, the geothermal fluid is piped about $300 \mathrm{ft}$ to the Aquaculture Facility for use as culture water and indirect heating. After exiting the Aquaculture Facility, the geothermal fluid is piped to the surface disposal pit. The surface disposal pit allows for percolation of the spent geothermal fluid to the aquifer. Depending on upstream demand and season, the exit geothermal fluid temperature can vary from less than $90^{\circ} \mathrm{F}$ to more than $125^{\circ} \mathrm{F}$.

\section{Geothermal Aquaculture Facility}

The geothermal water, that is ultimately discharged to a disposal pit, is the source water for heating the aquaculture production facility, but geothermal or fresh water can be used as culture water. The layout for the Aquaculture Facility is shown in Figure 2. Both intensive tank culture and extensive pond culture can be used for production. Two large, intensive tank culture systems are used to simulate commercial level 


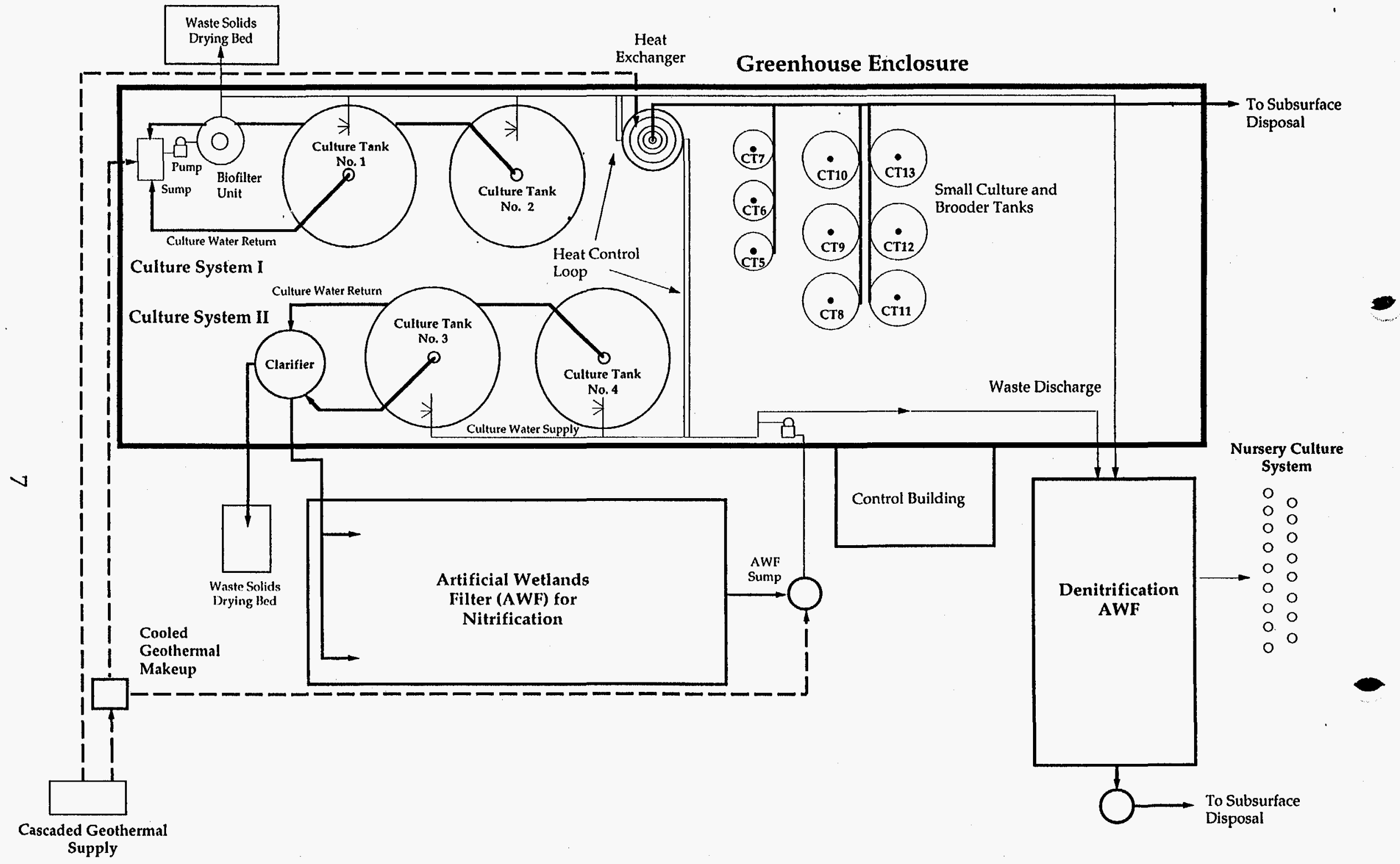

Figure 2. Process Flow Diagram for the Geothermal-Based Aquaculture Production System. 
production while a number of smaller tanks are maintained for brood stock and fry production. These tanks can be operated either with site-available geothermal or fresh water or they can be operated with batch mixed sea salts for marine culture applications. These systems are generally operated on a flow-through basis, but recirculating configurations are available.

The entire culture system is enclosed in a low-profile double-wall arched greenhouse structure, 30 feet wide by 100 feet long. Cooling and ventilation is provided by standard fan and cooling pad arrangement. All greenhouse and culture systems are computer monitored and controlled. Wastewater generated by the facility is treated by an artificial wetland filter designed specifically to remove nitrates prior to discharge to a surface disposal pit. However, most of the discharge is used for irrigating an adjacent nursery production system using crops such as afghan pines, Arizona cypress, and xeric species native to New Mexico as an added-value crop. This facility is designed to serve as both a research operation and as incubator space for lease to potential commercial culturists.

\section{A. Culture Systems}

Two independent, near commercial capacity, high density tank culture units are available to allow for multiple systems comparisons and for operational flexibility and offset production schedules. Each culture system consists of two 3,000 gallon (4 ft deep by $12 \mathrm{ft}$ diameter) fiberglass tanks and recirculating biofilter arrangement to maintain water quality and optimize water use rates. A centrifugal air blower provides oxygen input and circulation to the culture tanks. Air is introduced both by simple air stone 
aerators and air lift pumps. Each tank has about five of these units depending on culture densities. The system is flexible enough so that air stones can be easily added as production densities increase.

The recirculating biofilters for each system operate on a similar principal utilizing naturally occurring bacteria to effect the transformation of fish wastes containing $\mathrm{NH}_{3}$ and $\mathrm{NH}_{4}$ or total ammonical nitrogen (TAN), biological oxygen demand (BOD), total suspended solids (TSS), and settleable solids (SS). The major waste constituent is TAN which can be removed via the two-step nitrification process shown in Equations 1 and 2. This process consumes oxygen and alkalinity for each mole of ammonia converted to nitrate. If either oxygen or alkalinity or both are limiting,

Nitrosomonas

$$
\mathrm{NH}_{4}{ }^{+}+1.5 \mathrm{O}_{2}+2 \mathrm{HCO}_{3}^{-} \longrightarrow \mathrm{NO}_{2}^{-}+2 \mathrm{H}_{2} \mathrm{CO}_{3}+\mathrm{H}_{2} \mathrm{O}
$$

Nitrobacter

$$
\mathrm{NO}_{2}^{-}+0.5 \mathrm{O}_{2} \longrightarrow \mathrm{NO}_{3}^{-}
$$

the reaction will not proceed in optimal fashion. In addition, the reaction is limited by temperature, salinity, presence or absence of a carbon source, and $\mathrm{pH}$. Solids and other organic compounds increase the demand for $\mathrm{O}_{2}$ in the biofilter. The effective removal of solids in the sedimentation unit or through frequent back washing is imperative for effective nitrification (Bovedeur et al., 1990). In addition, the formation of $\mathrm{H}_{2} \mathrm{~S}$ and other potential toxic gaseous products from anaerobic processes could have detrimental impacts on the operation of high density, recirculating system. Both $\mathrm{NH}_{3}$ and $\mathrm{NO}_{2}$ are toxic to aquatic organisms at relatively low concentrations and the buildup of either molecule can result in increased system mortality. Thus, anything that impacts the 
efficacy of the nitrification process can result in the buildup of these components. A properly designed and operated biofilter system should provide a suitable environment for consistent and stable operation.

Culture system I (CS I) uses a commercially available bead filter (PBF-20 Model Biofilter) for solids removal and nitrification in one step as described by Malone et al., (1993). The system is manufactured by Armant Aquaculture, Inc. (Vacherie, LA). Culture water is transferred from the collection sump through the bead filter via a 1 h.p. centrifugal pump (Figure 3). The bead filter has a hydraulic volume of $75.3 \mathrm{ft}^{3}(562.9$ gal) and a hydraulic residence time of 22 minutes at the operational flowrate of $26 \mathrm{gpm}$. The beads provide a large surface area for attachment of microorganisms that act as a filter to remove suspended solids. Approximately $20 \mathrm{ft}^{3}$ of beads are provided with a specific surface area of $350 \mathrm{ft}^{2} / \mathrm{ft}^{3}$ giving a total surface area for microbial attachment of $6,400 \mathrm{ft}^{2}$. The total water volume of this system is 6,603 gallons.

The culture water is introduced to the 3,000 gallon culture tanks under pressure via multiple spray heads which provide oxygenation, $\mathrm{CO}_{2}$ stripping, and cooling through evaporation. The spray heads are directed to produce a circular rotation of water in the tanks which concentrates the fecal and food solids at the center current vortex where the water is discharged via a bottom-draw, 3-inch standpipe. This discharge flows by gravity to the sump where the effluent from both culture tanks are mixed and then pumped back through the filter system. The total system volume is about 6,603 gallons. Heat and evaporation losses come from the spray heads and from the culture tanks surface $\left(226 \mathrm{ft}^{2}\right)$. Direct energy consumption for CS I is from the continuous operation of a $3 / 4 \mathrm{HP}, 110$ volt centrifugal pump. 


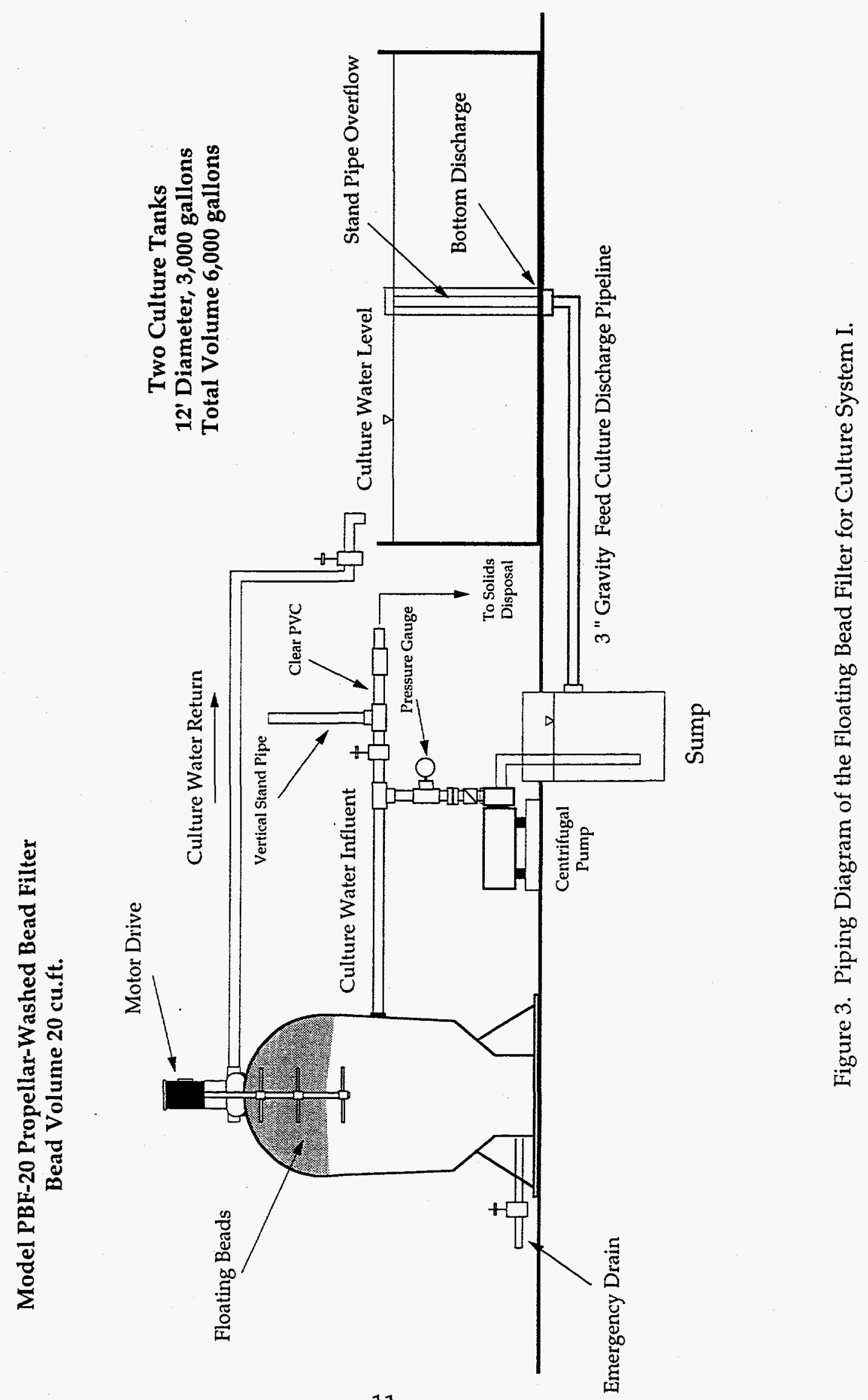


Solids in the culture water are removed by entrapment in the bead media. Collected solids are removed from the filter by a daily backwash process. The bead filter is shut off and a motor-driven propeller mixes the beads at a high rate for about 20 seconds. This mixing shears collected biomass and loosens growing nitrifying bacteria populations. This daily backwash assures that the nitrifying bacteria are always in a log phase of growth for maximum ammonia and nitrite removal. The sheared solids are allowed to settle for 5 to 10 minutes and then the solids concentrate are piped via gravity flow to a slow sand filter for solids separation. The slow sand filter removes solids at the sand surface and allows collected water to flow to a dry well for discharge. Water losses per backwash are estimated at 35 to 40 gallons.

CS II, uses a clarifier unit for solids removal and an artificial wetlands filter (AWF) or submerged surface constructed wetland for fine solids removal and nitrification as described by Zachritz and Jacquez (1993) and Zachritz et al., 1995. A 3-inch bottomdraw standpipe provides flow from each of the 3,000 gallon culture tanks to the 500 gallon sedimentation tank. The 500 gallon ( $6 \mathrm{ft}$ diameter) sedimentation tank is designed as a gravity settler to remove suspended and settleable solids. The unit has a hydraulic detention time of 16 minutes at the design flow and a surface settling rate of $1738 \mathrm{gpd} / \mathrm{ft}^{2}$. The waste flows from both culture tanks are introduced to the baffled center of the tank. The baffle ( $3.5 \mathrm{ft}$ diameter and $4 \mathrm{ft}$ deep), provides uniform mixing, prevents short-circuiting of floating solids, and directs the solids stream in a downward direction towards the conical solids collection zone of the tank. The collected solids are removed once per day via gravity flow pipeline to a drying bed for ultimate separation. Effective solids removal is critical to the long term operation of the AWF because 
excessive solids loading will decrease oxygen availability and result in low nitrification rates in the filter bed.

The culture water from the sedimentation tank overflows an internal weir structure and flows by gravity to the head end of the AWF unit. The layout for this unit is shown in Figure 4. The culture water is introduced by two, 4-inch pipes spaced $7 \mathrm{ft}$ apart at the head end of the AWF. The AWF unit is designed as a plug flow reactor and is $29 \mathrm{ft}$ long by $21 \mathrm{ft}$ wide giving an aspect ratio of 1.4. The reactor is 3.5 feet deep with an estimated volume of $2,168 \mathrm{ft}^{3}$ and a surface area of $619 \mathrm{ft}^{2}$. Culture water flows in a horizontal fashion through the 1.5 inch lava rock media. The media has a hydraulic conductivity of $141,000 \mathrm{ft}^{3} / \mathrm{ft}^{2} / \mathrm{d}$ and static porosity of 54 percent. At a flowrate of 30 gpm, the hydraulic residence time (HRT) in the system is $3.4 \mathrm{hrs}$. The total water volume of the AWF is 8,647 gallons and the total for the system 15,107 gallons.

At this time no additional $\mathrm{O}_{2}$ is added to the system, but different configurations such as partial recirculation or step feeding the influent can be used to increase $\mathrm{O}_{2}$ availability and nitrification. The treated water is collected by a submerged header that connects to an adjacent sump. Piping in the sumps sets the water level in the AWF unit. The sump is also piped to receive make-up water via a float valve. The culture water is then pumped back to the culture tanks for recycling. The total volume for CS I, including the AWF, is 15,100 gallons. Heat and evaporation losses come from the spray heads and from the culture tanks surface $\left(226 \mathrm{ft}^{2}\right)$ and AWF unit surface areas $\left(619 \mathrm{ft}^{2}\right)$. Direct energy consumption for CS I comes from a $3 / 4 \mathrm{HP}, 110$ volt centrifugal pump that operates continuously. 


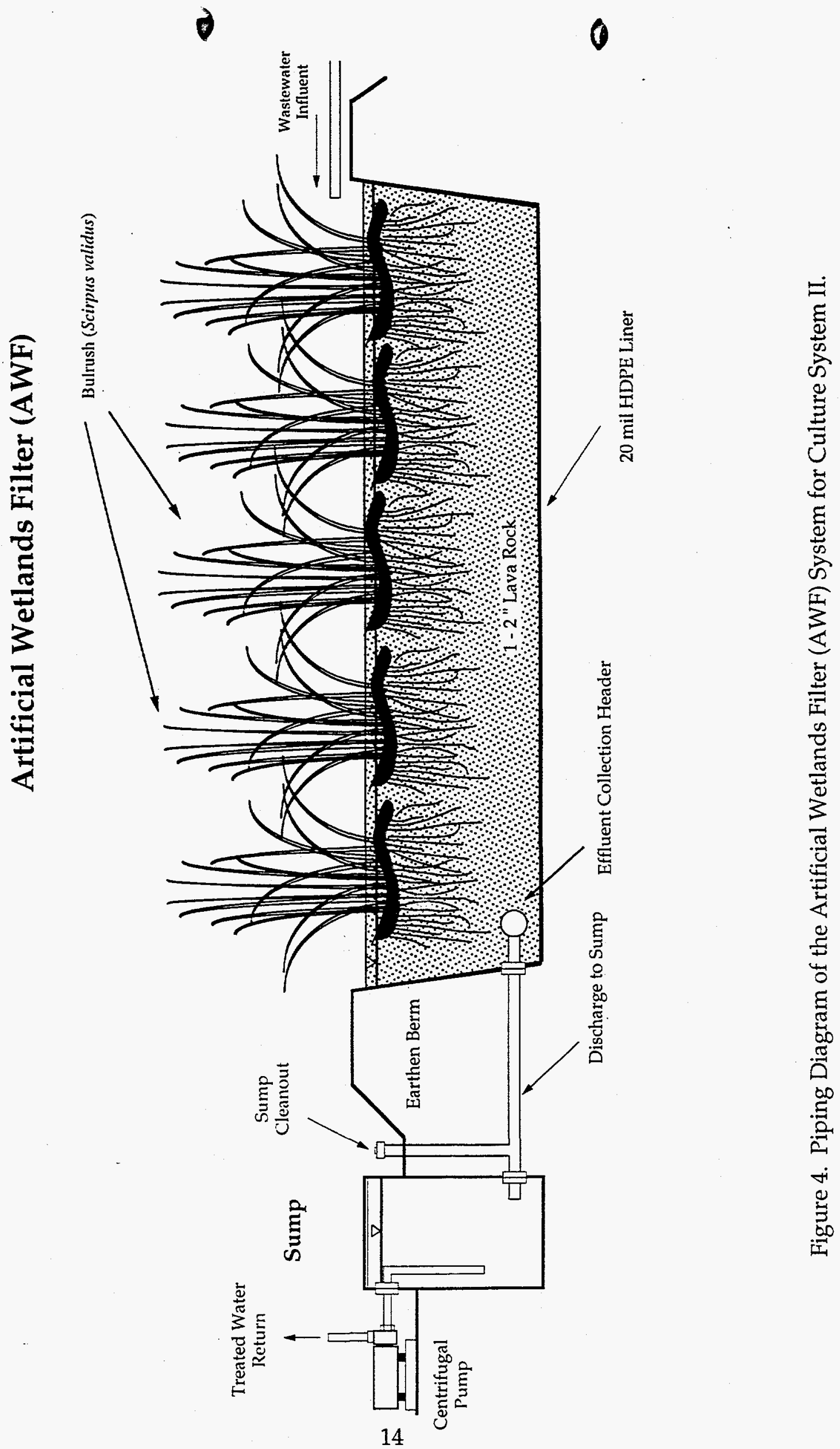


Discharge wastewaters from CS I and II are piped to the denitrification AWF unit which is $15 \mathrm{ft}$ wide by $38 \mathrm{ft}$ long giving an aspect ratio of 2.6. The unit is 4 feet deep with a surface area of $573 \mathrm{ft}^{2}$ and a media volume of $2,292 \mathrm{ft}^{3}$. The media is a 0.75 inch lava rock, with a hydraulic conductivity of $11,538 \mathrm{ft}^{3} / \mathrm{ft}^{2} / \mathrm{d}$ and a static porosity of 57.2 percent. At the design flowrate of $1,200 \mathrm{gpd}$, the HRT for the system is 5 days and the estimated system water volume is 9,806 gallons.

This AWF was designed as a denitrification unit to remove accumulated $\mathrm{NO}_{3}$ via bacterial activity to $\mathrm{N}_{2}$ gas. Denitrification is a two-step process in which the microorganisms use nitrate as an alternative electron acceptor in place of oxygen to convert nitrate to nitrogen gas (Equations 3 and 4). As opposed to

$$
\begin{aligned}
& \mathrm{NO}_{3}^{-}+0.33 \mathrm{CH}_{3} \mathrm{OH} \longrightarrow \mathrm{NO}_{2}^{-}+0.67 \mathrm{H}_{2} \mathrm{O} \\
& \mathrm{NO}_{2}^{-}+0.5 \mathrm{CH}_{3} \mathrm{OH} \longrightarrow 0.5 \mathrm{~N}_{2}+0.5 \mathrm{CO}_{2}+0.67 \mathrm{H}_{2} \mathrm{O}+\mathrm{OH}^{-}
\end{aligned}
$$

nitrification, a relatively broad range of environmentally robust microorganisms can accomplish denitrification. Critical to the completion of this process is the availability of a carbon source as represented by methanol in the equations above. The carbon source is oxidized and donates electrons and nitrate gains electrons and is reduced to nitrogen gas. Many different compounds can serve as carbon sources, but not all compounds result in an efficient conversion of nitrate to nitrogen gas. Acetate and methanol provide some of the best conversion rates for this process. Gersberg et al., (1984) reported removal efficiencies of 97 percent for total inorganic nitrogen (ammonia and nitrate) and 94 percent for total nitrogen (TN) are achieved via denitrification with methanol. Substituting plant biomass in the form of mulch as the carbon source resulted in the removal of 95 percent total inorganic nitrogen and 89 percent TN at 


\section{$\partial$}

hydraulic loading rates of 8.4 to $12.5 \mathrm{~cm} / \mathrm{d}$. The AWF unit designed for this system depends on plant biomass and BOD in the wastewater as a carbon source.

The culture systems should be able to maintain an ideal culture environment for various fish species at densities from 30 to $60 \mathrm{~kg} / \mathrm{m}^{3}$. In this mode, the system flowrates are about 25 to 30 gpm resulting in about 6 to 7 turnovers in the culture tanks per day. The fish are fed with automatic feeders that are reset once per day. The feed rate is about 3 to 5 percent of the fish biomass per day. The protein content of the feed varies between 25 and 50 percent depending on the size, species, and age of the fish.

Dissolved oxygen should be maintained in the range of 3 to $7 \mathrm{mg} / \mathrm{L}$ depending on the culture species.

\section{B. Temperature Control Systems}

During winter months the geothermal water temperature available for heating the Aquaculture Facility varies with the time of day. It ranges from 100 to $125^{\circ} \mathrm{F}$ with the warmest temperatures occurring during the day when no greenhouse heating is needed. Due to the thermal flywheel effect of the culture systems this does not present a problem in system control. Culture system heating typically starts during the night and continues into the day until system temperatures rise to the setpoints. Upon initiation of the heating cycle solenoid, valves are activated to divert the recirculation flow through the aquaculture heat exchanger. The recirculation water gains 4 to 6 degrees in the heat exchanger, depending on the geothermal temperatures in the heat exchange tank. 
The aquaculture heat exchanger (shown in Figure 5), is housed in a 550 gallon fiberglass tank, 30-inch tall and 72-inch in diameter and composed of two zones, one for each culture system. Each zone has three heating coils in parallel and each coil is mounted on a PVC angle frame in a vertical spiral. The coils are 1-inch Polyethylene (PE) pipe on 4-inch centers, with approximately 450 feet of PE pipe in the tank. The heat exchanger framework is bolted together and attached to the tank rim. Hot geothermal water enters the tank at the surface next to the rim and exits at the center of the tank from the bottom. The geothermal water is piped into the system to provide a circular counter flow parallel to the heating coils. During the heating season, the tank receives a continuous $16 \mathrm{gpm}$ flow of hot geothermal water to provide heat on demand. Upon exiting the heat exchange tank the geothermal water is piped to the surface disposal pit.

Cooling the system during the summer months can be done by increasing water recirculation rates and reducing culture waste rates. This decreases the heat added from hot make-up water and increases the cooling effects via the spray heads. This process can be operated independently of the heat system. The increased cooling effects can be accomplished by using the outdoor geothermal cooling pond as the source water. This storage pond could also be fitted with an active spray cooling system if high culture temperatures were persistent due to high air temperatures and solar insolation levels. 
莙营

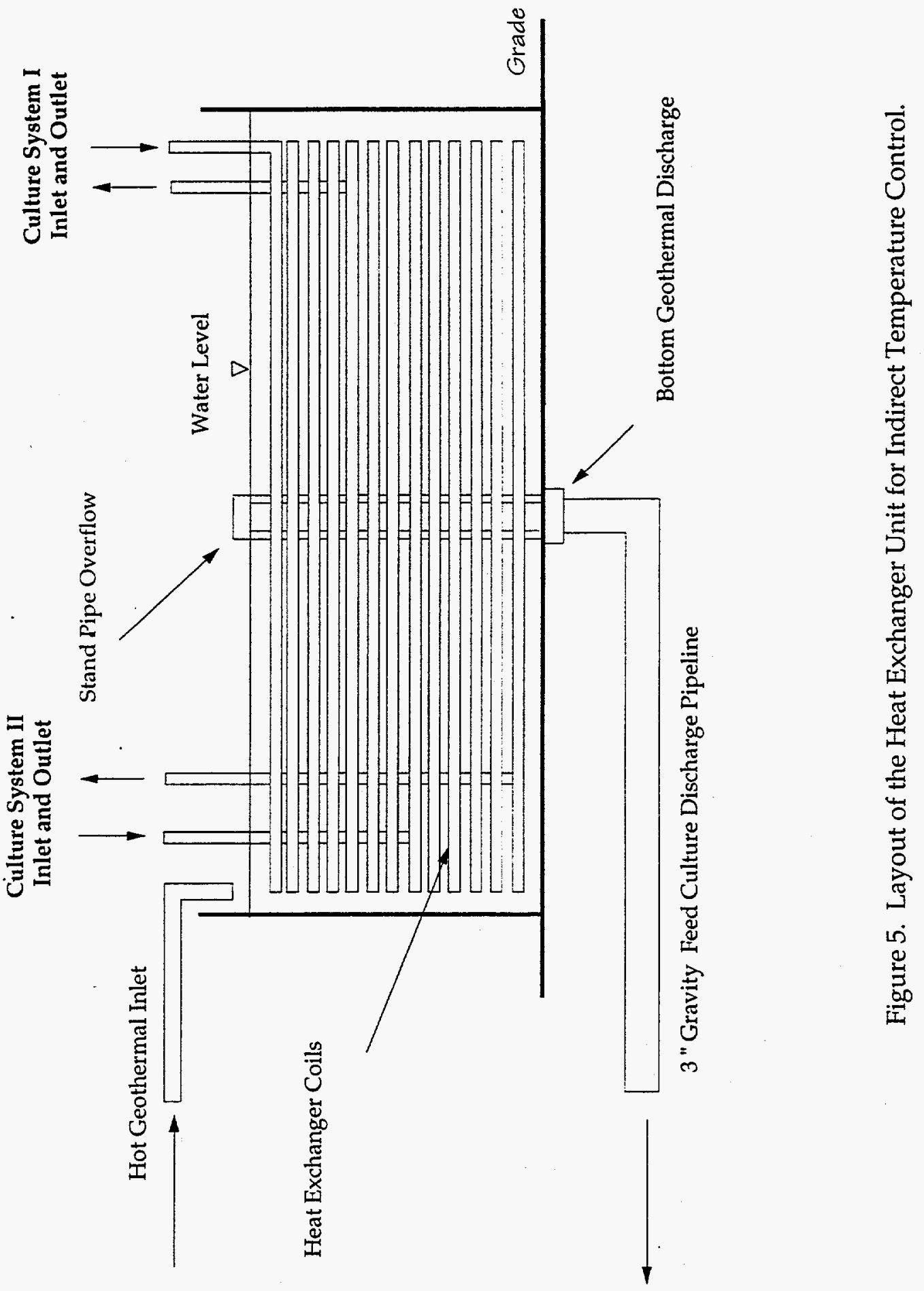




\section{Data Acquisition and Control System}

The facility is controlled by an IBM 386 personal computer operating in a Windows $\mathrm{S}^{\mathrm{TM}}$ environment with Keithley Metrabyte data acquisition and process control boards. A Keithley DASTC thermocouple board is used for monitoring system temperatures and low voltage DC inputs such as Oxygen Reduction Probes (ORP). Temperature sensors are located in all culture tanks, the make up water stream, the inlet and outlet of the heat exchange headers for each culture system, the heat exchange tank inlet and outlet, the greenhouse environment, and ambient air. Additional temperature and energy use monitoring of the geothermal greenhouse facility is accomplished through the use of the IBM XT and Keithley 500 Workstation that operates the Incubation Greenhouse facility. This system collects data on energy use derived from the geothermal fluid upstream from the Aquaculture Facility.

Process control is accomplished through the use of a Keithley PIO-24 Digital Input/Output board that powers a Keithley SSIO-24 solid state relay and input module board. In PIO-24 and SSIO-24 boards provide direct relay operation for process equipment control and contact closure monitoring for process status evaluation. The system hardware runs under Labtech Notebook Pro, a Windows-based package designed for multi-point industrial process system monitoring and control. Data relative to culture conditions, energy flows, and ambient weather conditions is collected. Real-time plots of data are available for immediate inspection of operating conditions. Currently, the software collects data five times per minute, averages it five times per hour and stores the data daily in ASCII files for further processing and analysis. 


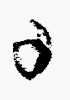

\section{Methods}

The SWTDI Geothermal Aquaculture Facility was funded by the U.S. Department of Energy in February 1993. The project contract was received by SWTDI on February 24, 1993. At that time detailed planning and engineering on the project began. In March, a site plan was developed and presented to the NMSU Planning Board for approval. Site preparation and fence erection was completed by April 1993. Facility engineering and equipment and materials procurement began in March 1993 and continued throughout the calendar year. Construction of the greenhouse and the installation of facility utilities began in July and continued until November when the structure was completed except for the evaporative cooling equipment. Construction of the culture systems began in August 1993 and were completed in June 1994. They comprise two intensive growout systems of 6,000 gallons capacity each and several small systems that are utilized for breeding and fry and fingerling culture.

Hybrid Tilapia were first moved on site in December 1993 and placed in a temporary culture system until CS II was completed in April 1994. Shortly after the completion of CS I in June 1994, Hybrid Striped Bass were introduced into the facility. Throughout the summer of 1994 the Tilapia population grew by reproduction on-site in the culture tanks. The fry were grown out in the small auxiliary systems. During the rest of 1994, the operations of the culture systems were modified and fine tuned as required. Routine maintenance and system repairs were carried out when necessary. The computer system for facility monitoring and control was installed and brought online in December 1994. The facility computer system has been operating under Labtech 
Notebook software since January 1995. Collection of temperature data and other relevant parameters is still in progress.

Data acquisition during facility operation was achieved through the use of Labtech Notebook-Pro software with a Zenith 386 personal computer. The Labtech setup operated in the Windows ${ }^{\circledR}$ environment. Parameters of interest included culture system water temperatures, greenhouse air and outside ambient temperatures, heat exchanger coil inlet and outlet temperatures for each culture system, and oxygen reduction potentials (ORP) for each culture system. Temperatures were recorded by the Keithley DAS-TC board utilizing potted type $\mathrm{T}$ (Copper-Constantan) thermocouples. The temperature sensors were fabricated by potting soldered thermocouple junctions in spun closed copper tubing with waterproof epoxy. The copper protection tubes were painted with stainless steel paint and the tube-wire interface was sealed with thermal heat shrink tubing. Each of the four 3,000 gallon tanks contained its own temperature sensor suspended at the tank perimeter halfway to the bottom. Air temperature sensors were made from soldered junctions with a sprayed-on coating of insulating varnish. The sensors used for monitoring the heat transfer from the geothermal fluid to the culture systems were potted in stainless steel protection tubes with epoxy. These tubes were then located in the culture water recirculation pipe before and after the heat exchange coils. The protection tubes were inserted into the fluid stream through the use of plastic compression fittings with rubber O-rings. All thermocouple sensors were wired to the Keithley DAS-TC board terminal block in a continuous wire run with no splices. The ORP sensors were commercially available probes with internal reference junctions. These probes produced a DC voltage proportionate to the available oxygen 


\section{J}

in the culture media. Each culture system had one ORP probe located near a tank temperature sensor. Additionally, CS II had an ORP probe located in the middle of the nitrification AWF to monitor the status of ammonia conversion within the AWF.

Data was collected conducting block averages of instantaneous measurements that were stored on disc. The slowly changing nature of an operating Aquaculture Facility reduces the need for high scan rates. After observing the magnitude and speed of diurnal temperature fluctuations, a scan rate of 12 seconds was chosen for instantaneous measurements. These scans were averaged in blocks of 60 data points every 12 minutes and stored on file. This produced 120 data points per day for each monitored channel and data was organized into daily files, each beginning at midnight. Each daily file contained records of 13 points for temperatures and 3 points for ORP. These were written to separate files comprised of 120 records per file at the end of each day. The files are transferred to floppy discs for analysis on Excel spreadsheets on a regular basis. During data analysis, the energy flows within the Aquaculture Facility are calculated for each culture system.

Initially, each day of data was examined for inconsistencies in scan times or values, and anomalies that arose from shutting down the recirculation flow, disabling the geothermal heat source or other operational actions relating to data quality. The raw data from each day was broken down into data files pertaining to each culture system with relevant data only, such as temperatures from both tanks, temperatures before and after the heat exchange coil solenoid valves, make-up water temperatures, and greenhouse air temperatures. The temperatures at the heat exchange coil solenoids were graphed and analyzed visually for the current absolute error between the two 
thermocouples. Typically, this varied from 1.5 to $2.5^{\circ} \mathrm{F}$. Generally, the first thermocouple in the pipe (which would be the cooler temperature when heat was enabled) produced a higher value than the second thermocouple. Before or after system heating, a parallel section of the chart was chosen for determining of the magnitude of error between the two thermocouples. A period of at least one hour was preferable for this operation. The spreadsheet was then examined to determine the magnitude of error and a correction was applied to the heat exchange coil outlet temperature to bring the two thermocouples into agreement during a period of no heating where the temperatures must remain equal. Changing the value of one thermocouple over the 24hour file moved the two temperature plots together so they overlapped during periods of no heating. Determining heating periods then becomes relatively straightforward. The energy flows into the system then proceeded along the 12 minute scan intervals.

The basic energy balance can be described as follows:

$$
q_{\text {total }}=q_{\text {hx }}+q_{\text {solar }}+q_{\text {make-up }}-q_{\text {evap }}-q_{\text {conv }}-q_{\text {bwash }}
$$

Where (all values BTU/day):

$\mathrm{q}_{\mathrm{hx}}=$ Energy gain to the aquaculture systems from the heat exchanger;

$\mathrm{q}_{\mathrm{solar}}=$ Energy gain from solar irradiance;

$q_{\text {make-up }}=$ Energy gain from the culture system geothermal make-up water;

$q_{\text {evap }}=$ Energy loss from culture system evaporation and water loss from tanks;

$\mathrm{q}_{\mathrm{conv}}=$ Energy loss from thermal convection; and

$\mathrm{q}_{\mathrm{bwash}}=$ Energy loss from the backwashing the system.

The energy entering and leaving each system can be described in Equations 6 and 7, respectively: 


$$
\begin{aligned}
& q_{\text {in }}=q_{\text {hx }}+q_{\text {solar }}+q_{\text {make-up }} \\
& q_{\text {out }}=q_{\text {evap }}+q_{\text {conv }}+q_{\text {bwash }}
\end{aligned}
$$

$\mathrm{q}_{\mathrm{hx}}$, the heat exchanger output was calculated from Equation 8

$$
\mathrm{q}_{\mathrm{hx}}=\mathrm{C}_{\mathrm{p}} *\left(\mathrm{HX}_{\mathrm{r}}-\mathrm{HX}_{\mathrm{s}}\right) * \mathrm{Q}
$$

where:

$\mathrm{C}_{\mathrm{p}}=$ Specific heat capacity of water, $\left(=1 \mathrm{BTU} / \mathrm{lb}{ }^{\circ} \mathrm{F}\right)$;

$\mathrm{HX}_{\mathrm{r}}=$ Heat exchanger return temperature, ${ }^{\circ} \mathrm{F}$;

$\mathrm{HX}_{\mathrm{s}}=$ Heat exchanger supply side temperature, ${ }^{\circ} \mathrm{F}$; and

$\mathrm{Q}=$ Geothermal fluid flowrate, lbs/day.

When the heat exchanger was in operation, the temperature differential across the heat exchange coils was multiplied by the mass flowrate and specific heat of the geothermal fluid. The daily total heat exchanger run time and hourly average output were calculated and stored for further analysis.

$q_{\text {solar }}$ represents the daily summation of global horizontal solar energy incident to the tank surfaces. This value is dependent upon the solar transmissivity of the greenhouse glazing and protective shadecloth and the absorbance of the water surface. The daily total was calculated from these factors and the daily total solar radiation recorded outside the greenhouse.

$q_{\text {make-up }}$ represents the energy gain or loss associated with the culture water that leaves the system as waste water and entered as make-up water. Generally, this occurs as an energy gain when slightly warmer make-up water replaces the waste water and water losses associated with backwashing of sedimentation tanks and filters. 
$q_{\text {evap }}$ represents the daily loss associated with evaporation from the tanks and spray heads and with CSII the evaporation and transpiration that occurred in the nitrification AWF. This also included losses associated with water loss from the system due to spillage and splashing by the fish. This water loss from the systems cannot be measured due to the random nature of its occurrence. Heat losses from evaporation were calculated from the difference in daily waste and make-up flows minus a fixed value for backwash gallons times specific heat $(C p)$.

$q_{\text {conv }}$ comprises system heat losses due to natural convection from tank walls and surfaces. Convective heat losses were calculated by summing the losses from all tank horizontal surfaces and all tank vertical surfaces. The magnitude of these losses dependent upon the temperature differential between the tank and the surrounding air.

$q_{b w a s h}$ comprises system heat losses that occurred during the draining of culture water from the systems for removal of solids wastes in the recirculation stream. In addition to monitoring the energy flows within the Aquaculture Facility, the geothermal fluid temperatures are recorded at various points along the pipeline from wellhead to the disposal pit. From these temperatures and a known flowrate the gross heat transfer to various components of the facility heating systems can be determined. Energy extraction from the geothermal greenhouse stainless steel plate-to-plate heat exchanger that serves the greenhouse facility air heating system was calculated based on heat exchanger inlet and outlet temperatures. The energy use calculated at this point included air space heating for $12,000 \mathrm{ft}^{2}$ of greenhouse space plus system losses within the facility equipment room and underground pipe losses. During greenhouse operation, the geothermal fluid was piped to the two horticulture greenhouses to be 
used for heating $8,300 \mathrm{ft}^{2}$ of bench space. The geothermal energy was used without a heat exchanger because system components were not affected by the high mineral content of the water. The energy flow to the greenhouse benchtop heating systems was calculated by monitoring inlet and outlet temperatures for each greenhouse bench heating system. Upon exiting the greenhouses the geothermal fluid is piped to the Aquaculture Facility for use as a culture medium and for system heating.

Energy flows from the geothermal fluid as it was used in the Geothermal Greenhouse Facility were calculated from data obtained from the computer-based control system that operates the facility. An IBM XT personal computer was used in conjunction with a Keithley 500 Scientific Work Station. The data collection and facility control software was an in-house program written in Quickbasic and the Keithley 500 command language. Temperature data was recorded by the use of type $\mathrm{T}$ thermocouples. This data is comprised of 1-minute scans averaged every 6 minutes and stored in daily files. Facility weather data was also generated by this computer. Greenhouse environmental control was managed by the IBM computer, based on data collected by the Keithley 500 .

The geothermal fluids used in the Aquaculture Facility are the third use of the water for heating in a cascaded system. The hot water was used in two distinct heating applications in the horticultural greenhouses for sir space heating and benchtop heating of the soil in flats and pots. When the geothermal fluids arrive on the Aquaculture Facility, the temperature can vary from 95 to $135^{\circ} \mathrm{F}$, depending on the upstream heating loads. This water was used to heat the recirculation flow indirectly as needed in order 
to maintain an optimum culture temperature. In addition, the geothermal fluid was also the make-up water supply, where it came from an outdoor cooling pond.

Water balances for the systems, described by Equation 9, were determined by measuring the flowrates for the culture systems

$Q_{\text {make-up }}=Q_{\text {waste }}+Q_{\text {evap }}$

where:

$\mathrm{Q}_{\text {waste }}=$ amount of water wasted, gpd;

$Q_{\text {make-up }}=$ total amount of water added to the system, gpd; and

$\mathrm{Q}_{\text {evap }}=$ amount of water lost from the system by evapotranspiration, gpd.

Make-up and waste water flowrates were measured directly using positive displacement flow meters and evapotranspiration losses were calculated from these values. Additional data regarding fish growth were determined by weighing 20 randomly collected fish from each of the four tanks about every two months.

\section{Results and Discussion}

Energy Balance: The Aquaculture Facility is located downstream of the Geothermal Greenhouse Research Facility that is currently occupied by a commercial grower producing a large variety of cactus species for the wholesale market. The hot geothermal fluid as it comes out of the ground serves the horticultural greenhouses first, due to their higher temperature heating requirement. After the greenhouses extract heat for use in air space heating and bench top soil heating, it piped to the Aquaculture Facility for use as culture water and in heating the culture water. The 
temperature of the geothermal fluid as it comes from the wellhead is nearly constant throughout the day and does not vary seasonally.

As the fluid was used and cascaded down to subsequent heating systems, the temperature dropped at widely varying rates. Figure 6 illustrates this phenomenon for a typical day, in this case March 14, 1995. The line on the chart labeled "Air Heat" represented the temperature at the inlet to the plate and frame heat exchanger and was nearly constant at $145^{\circ} \mathrm{F}$. The line labeled "Bench Heat" represented the temperature at the beginning of the bench top soil heating systems in the horticultural greenhouses. During the early part of the day (1:00 a.m. to 7:00 a.m.), the sharp temperature variations were caused by cycling of the air heating systems in the horticultural greenhouses. Every time the fan-coils in the greenhouses were on, it depressed the temperature of the geothermal fluid as more heat was extracted. After 7:30 a.m. greenhouse air space heating ceased and the difference between the two lines represented the heat losses incurred in the warehouse at the heat exchanger and in ground losses through the buried pipeline. It should be noted that there was not a pronounced cycling effect occurring at the end of the day as would have been expected. This was due to the fact that the ambient temperatures at the end of the day were warmer than the temperatures at the beginning of the day. The greenhouses have a night time air heating setpoint that was lower than the soil heating setpoint. Under these conditions where the overall heating load was relatively low, the entire heating requirements were met by the bench top soil heating systems. The dotted line below that represented the temperature at the Aquaculture Facility heat exchange tank inlet. 


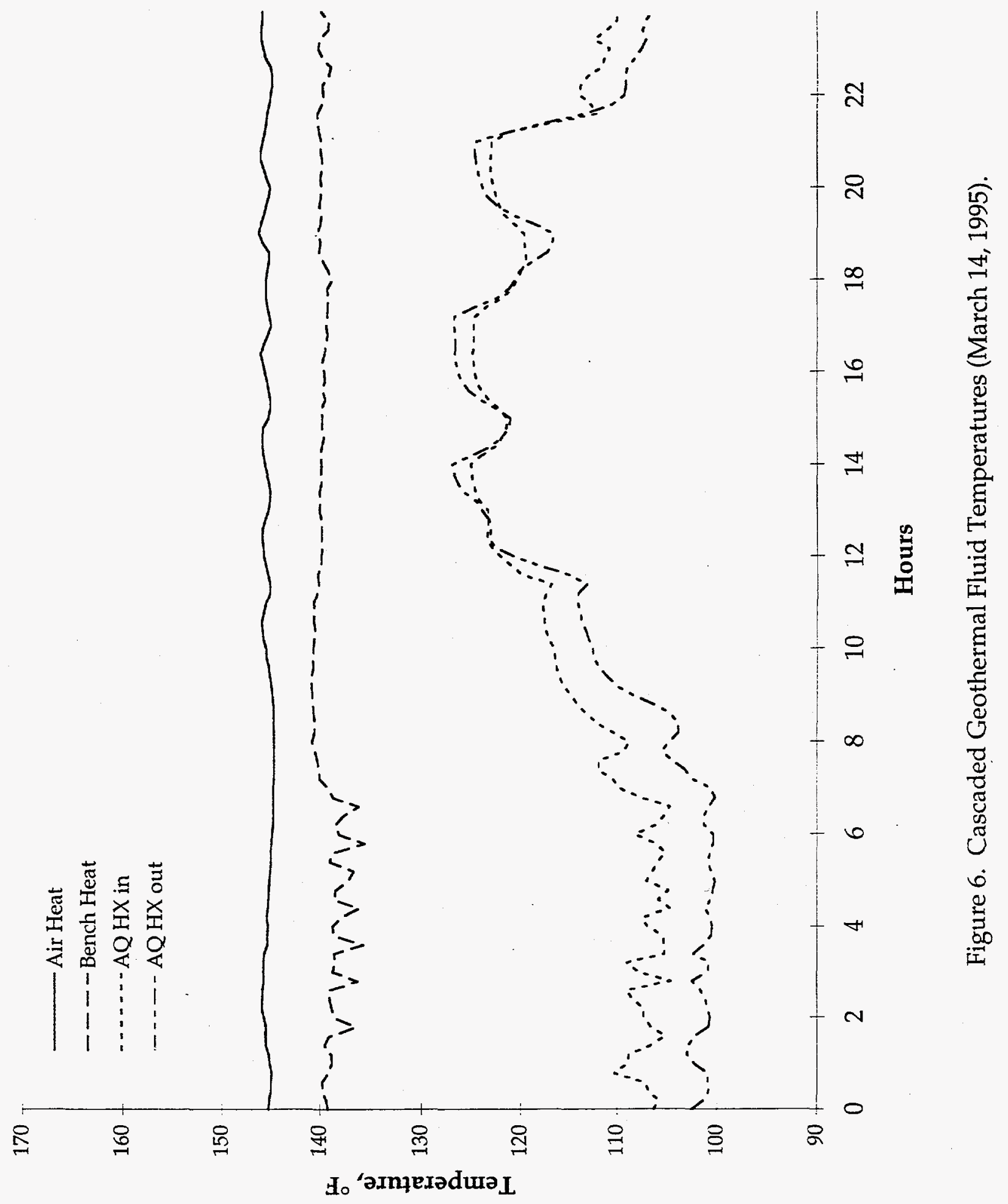


The variations in the temperature during the first 8 hours of the day were more pronounced at this point because of the added cycling of the bench heating systems during the night. As daylight arrived and the greenhouse heating systems shut down the temperature of the geothermal fluid at the heat exchange tank inlet rose dramatically. The difference between this temperature and that of the last line, the heat exchange tank outlet temperature, is that it is directly related to aquaculture heating operations and heat exchange tank losses. Between the hours of 1:00 p.m. and 9:00 p.m. wide fluctuations in temperatures at the heat exchange tank were observed. This occurred during cycling of the aquaculture heating systems during the afternoon. After 9:00 p.m. the system settled down to a steady heating operation for the remainder of the day.

Figure 7 illustrates culture temperatures during the course of the same day, March 14,1995 . The solid line in this figure represents the average culture water temperature of the two tanks comprising CS I. The dashed line represents the culture water temperature after the bead filter prior to branching off to the heat exchange coil. The dotted line was the culture water temperature after it returned from the heat exchange coil. It was noted that steady state heating occurred during the first 8 hours of the day. During this time, the culture water temperature rose slowly. At 8:30 a.m. the heating system shut down and the culture temperature slowly drifted downward within the setpoint deadband. The decrease in culture temperature continued until 9:00 p.m., when heating resumed for the remainder of the day. A pronounced spike in temperatures was observed at 12:00 p.m. This was caused by daily backwashing and bead filter flushing. During this operation where the circulation pump was shut down, 


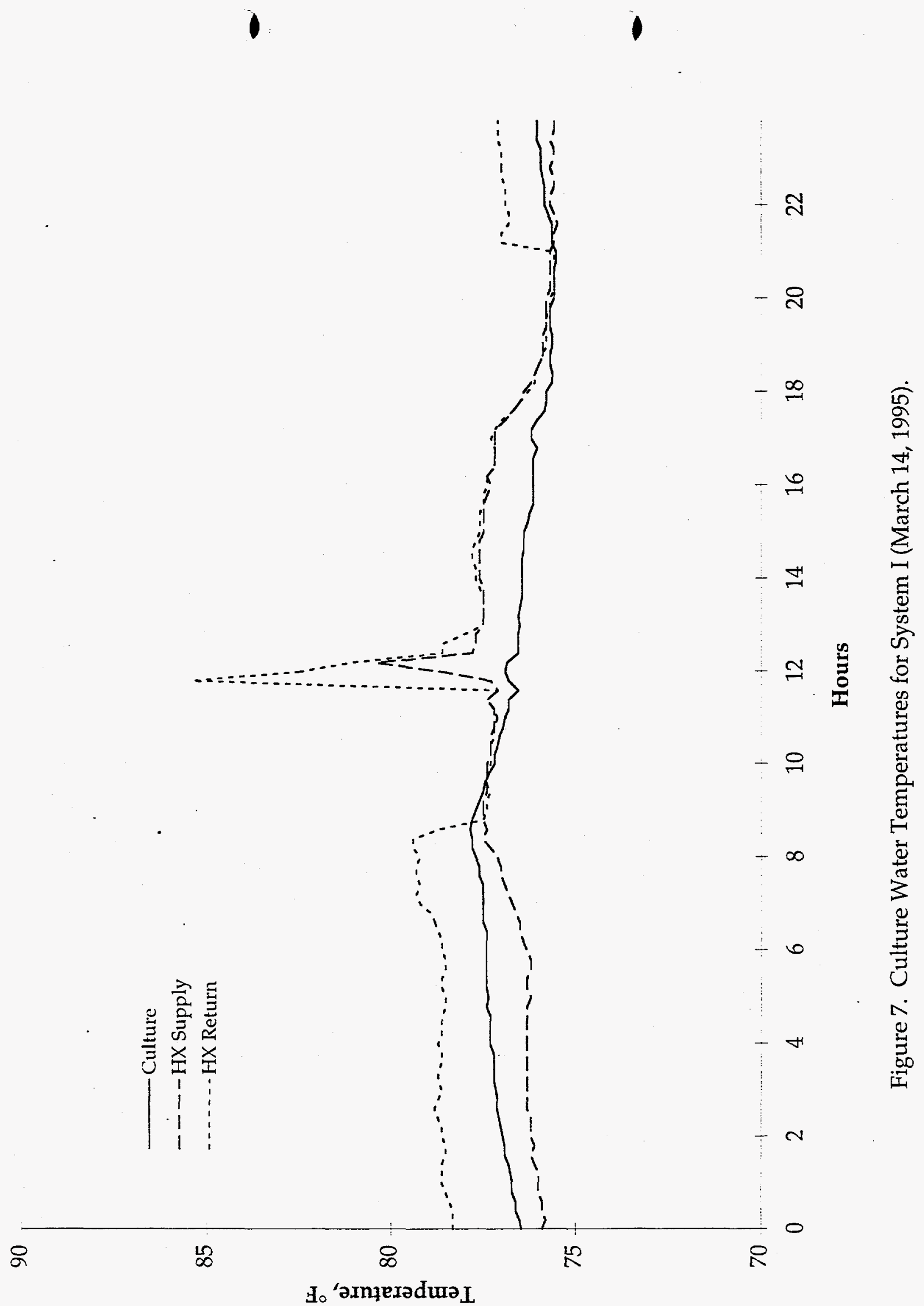


the water drained out of the heat exchange coil return pipe leaving the temperature sensor exposed to air within the pipe that heated due to solar gain. Examination of the culture temperature data indicated that the heating system controls maintained an acceptable temperature throughout the day with little variation. The differential between the daily minimum culture temperature and the daily maximum culture temperature was $2.3^{\circ} \mathrm{F}$.

Figure 8 also illustrates culture temperatures during the course of March 14, 1995. The solid line in this figure represents the average culture water temperature of the CS II. The dashed line represents the culture water temperature after the bead filter before branching off to the heat exchange coil. The dotted line represents the culture water temperature after it returned from the heat exchange coil. During the night the heating system operated continually. Because the water temperature entering the tanks from the heat exchanger was lower than the tank temperature, the culture temperature slowly decreased throughout the night. This occurred when the culture water passed through the nitrification AWF during cold weather and lost heat to the atmosphere and the surrounding earth. At approximately 8:30 a.m. the horticultural greenhouse heating systems went off for the day, which allowed the culture water heat coil return water to rise rapidly in temperature, and brought the culture temperature up with it. In response to this process, the system cycles throughout the day as needed on approximately 3-hour intervals. The plot of the heat exchange coil supply temperature was comparable to the temperature of the water exiting the nitrification AWF. This plot shows the effects of solar gain on the black volcanic rock surface of the nitrification AWF. At about 9:00 p.m., the heating system was turned on for the remainder of the 


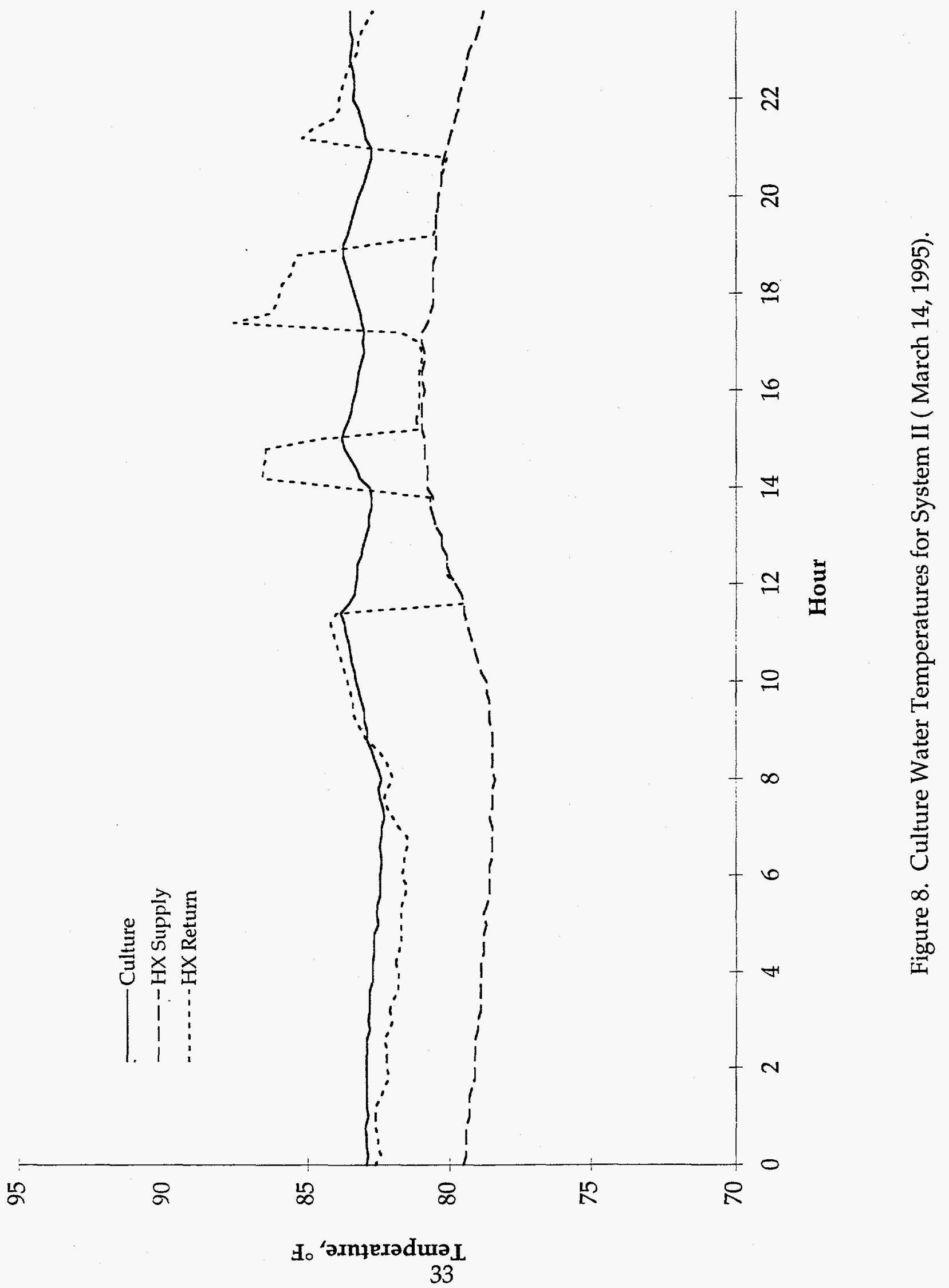


day. At the end of the day, the heating coil return temperature dropped below that of the culture tanks. At this point, the culture tank temperatures started to decrease again and continued to do so until the following day. Examination of the cultured temperature data indicates that the heating system controls maintained an acceptable temperature throughout the day with little variation. The differential between the daily minimum culture temperature and the daily maximum culture temperature was $1.6^{\circ} \mathrm{F}$. This is well within the limits required for Tilapia production.

The two month period of February and March 1995 was examined for trends in energy use in the Aquaculture Facility. Figure 9 illustrates this for CS I. The area graph has two sectors above the $x$-axis that correspond to energy inputs to the system. These are solar gain $\left(\mathrm{q}_{\text {solar }}\right)$ and indirect geothermal heating via the coils in the heat exchange $\operatorname{tank}\left(q_{h x}\right)$. The solar gain is relatively constant during the two month period except for an occasional cloudy day (here in the Chihuahuan desert). It may be noted, however, that there was a slight but steady increase as the season progresses that corresponds to the increasing day length. The daily variation in the energy supplied by the heat exchange coil is much larger. This is believed to be caused by a number of interacting factors, most notably meteorological, such as ambient temperature, windspeed and humidity. One other energy gain is present but in quantities too small to appear on the chart. That is the energy supplied to the system by the slightly warmer make-up water. It is on the order of several thousand BTUs per day which disappears as background noise in the scale of this chart. The two major components of heat loss are thermal convection $\left(\mathrm{q}_{\text {conv }}\right)$ and evaporation $\left(\mathrm{q}_{\text {evap }}\right)$. Convection is primarily driven by the temperature differential between the culture tanks and the greenhouse air. Early in this 


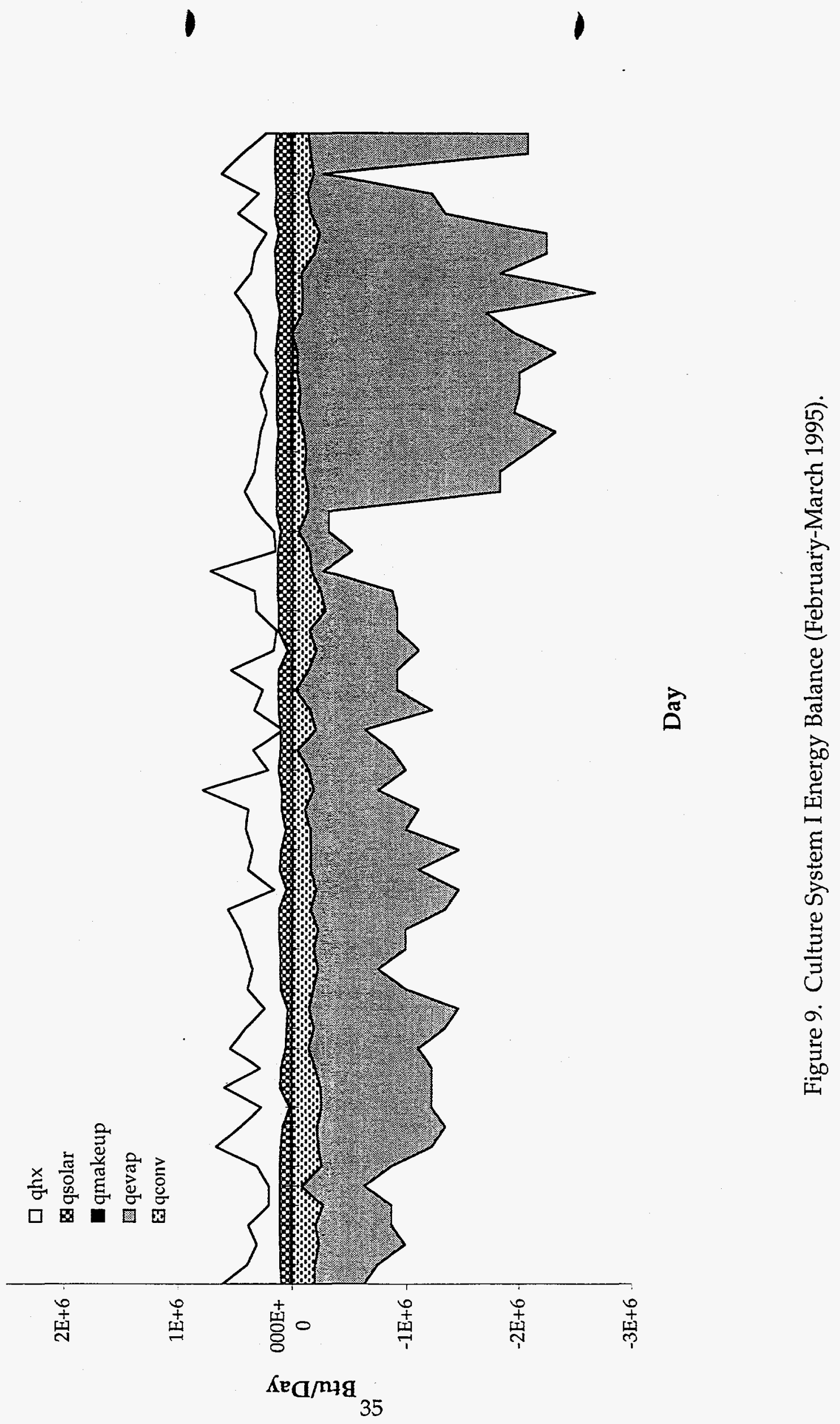


time period (February) the magnitude of this loss is greater. As the ambient temperatures increase with the approaching spring, the convective losses gradually diminish. The last and largest component of heat loss in the aquaculture system is evaporative heat losses. This is driven by high vapor pressures at the water surface. It may be noted that the magnitude increases with time which is due to the warming of the greenhouse environment as the sun's declination increases. This causes more ventilation by the exhaust fans during the day. In addition, as spring in the desert approaches the humidity decreases with a corresponding increase in the evaporation rate. The evaporative losses for this system also include mass losses from the system caused by direct water loss. CS I contained Hybrid Striped Bass which are active, splashy feeders, which caused an unknown quantity of water to be lost every day. This mass loss had to be accounted for as an evaporative loss because the equipment required to monitor environmental conditions necessary for calculating evaporative losses was not available.

Figure 10 illustrates energy use during February and March 1995 CS II. The form of the area graph is identical to that described in the preceding paragraph. The portion of the energy flow contributed by the geothermal heating coil is quite large. This occurs because of a relatively high setpoint of $82^{\circ} \mathrm{F}$ for Tilapia culture. It can be seen to decrease slowly over the two month period as the approaching spring warming decreases the heating load. During this time the solar heat gains increase and the convective heat losses decrease due to interior greenhouse warming. The heat loss component attributable to evaporation and water loss is much lower for CS II than CS I. The feeding behavior of Tilapia can account for this difference in that the Tilapia are 


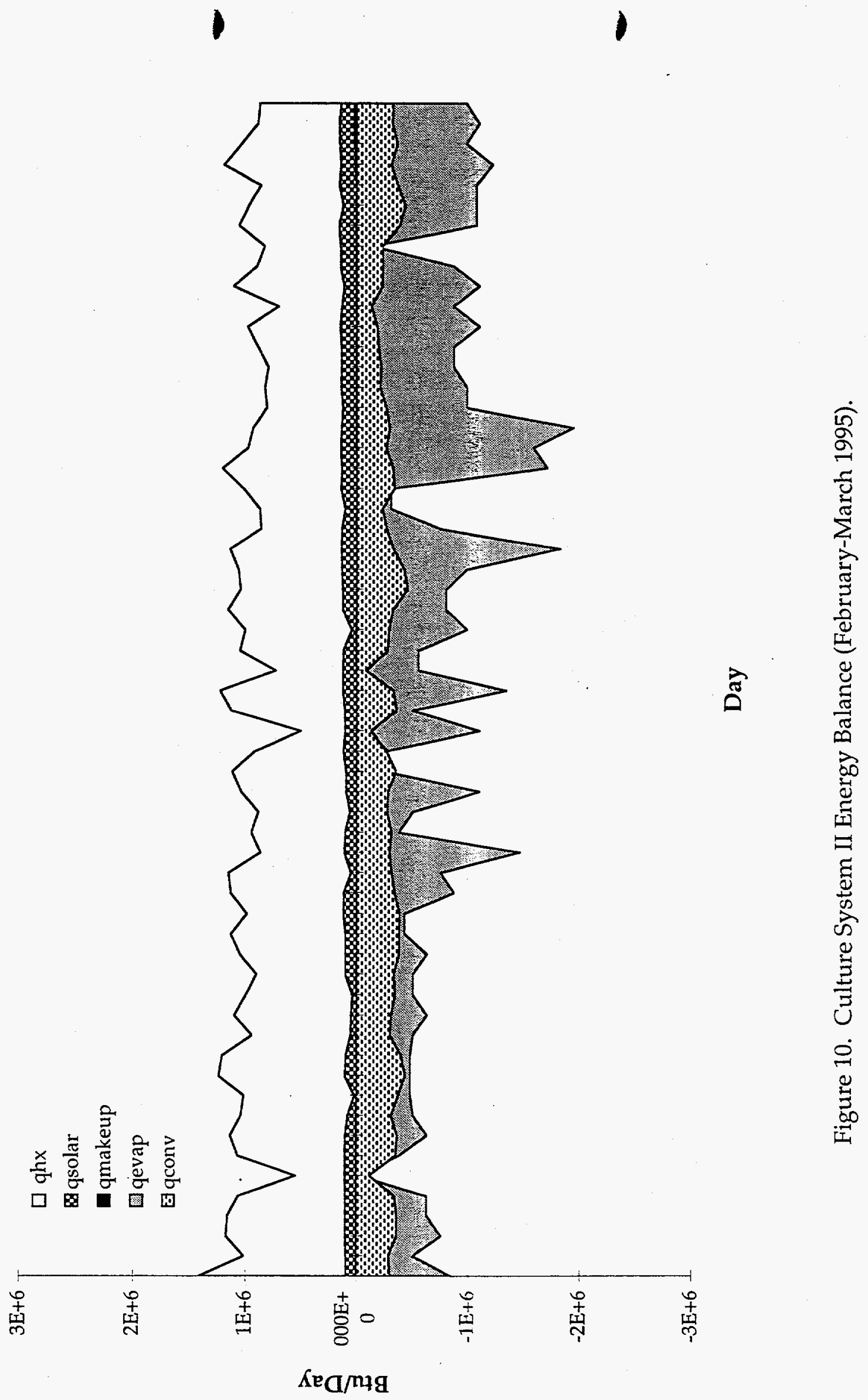


passive feeders that do not splash water out of the tanks. Large values for evaporative losses can be seen intermittently during this time frame. These losses arise from individual events relating to water loss from the system. Some of the large losses arise from system maintenance to the sedimentation tank when it requires draining for cleaning. Another cause of large evaporative losses occurred when the system make-up water float valve stuck partially open allowing extra water to entire the system sump where it was then discharged out through the nitrification AWF overflow pipe.

The overall energy use of the Geothermal Greenhouse Research Facility and the Aquaculture Facility for the period of February and March 1995 is shown in Figure 11. Energy use is broken down into the discrete components of the various heating systems within the facility. The largest component is that of the Geothermal Greenhouse air heating system which serves both horticultural greenhouses and also encompasses losses to the warehouse environment where the heat exchanger is located and pipeline losses. As the geothermal fluid flowed down the pipeline, the next usage occurred at the bench top soil heating systems. The system for north greenhouse soil heating used more than twice as much energy as that of the south greenhouse. This occurred because the north greenhouse system is larger than the south greenhouse system $(5,000$ square feet as opposed to 3,200 square feet) and the fact that the building heat loss for the north greenhouse is greater than that of the south greenhouse. The last heating application in the pipeline is that of the Aquaculture heating systems. Here it is also readily apparent that CS II had a substantially larger heat load than that of CS I. This was due to a higher 


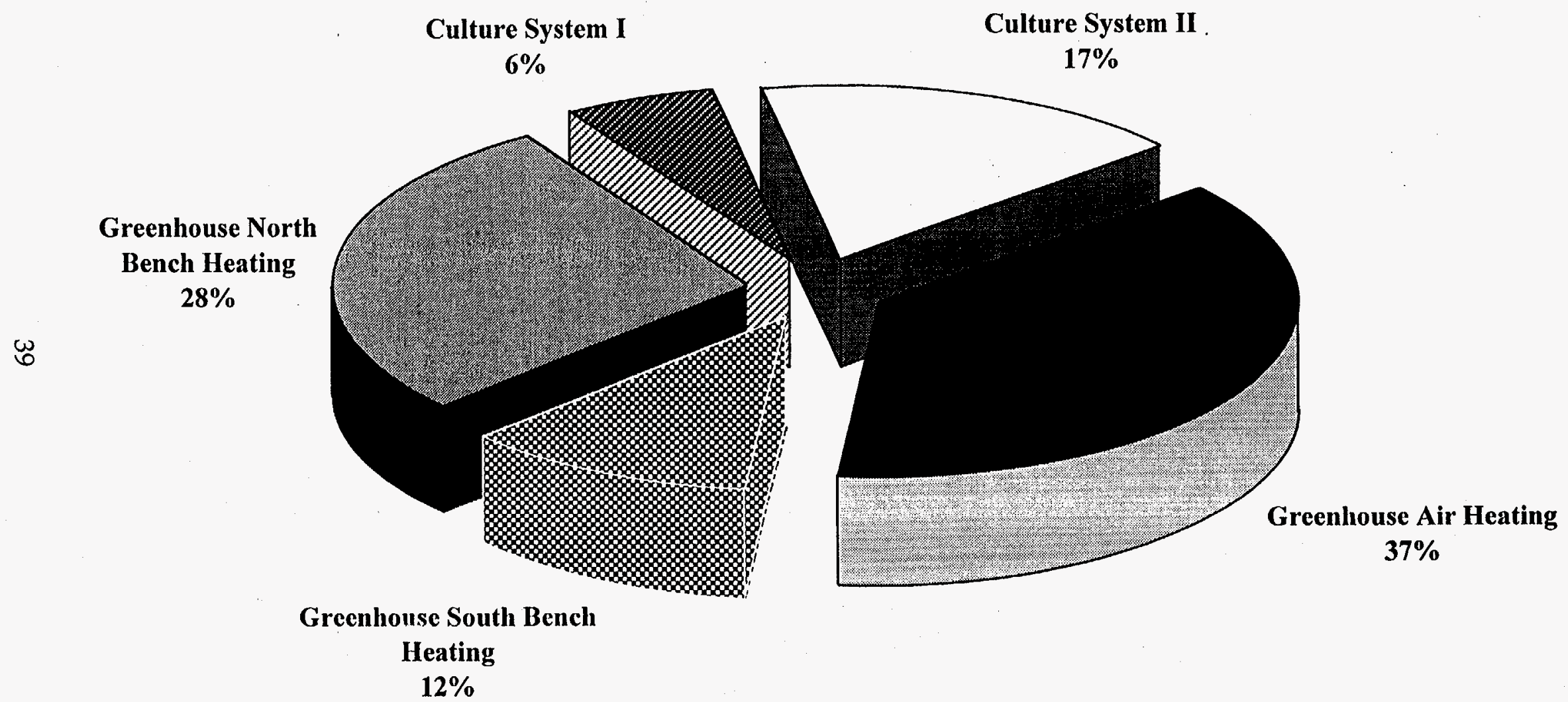

Figure 11. Geothermal Use by Application (Febuary-March 1995). 
setpoint for CS II (approximately $6^{\circ} \mathrm{F}$ ). Additionally CS II had large losses to the outside environment when the culture water flowed through the nitrification AWF. Total BTUs of geothermal energy utilized by the systems is presented in Table 1.

Table 1. Geothermal Energy Consumption During February-March 1995

\begin{tabular}{rcccc}
$\begin{array}{c}\text { GH Air } \\
\text { Heat } \\
\text { BTU }\end{array}$ & $\begin{array}{c}\text { GH South } \\
\text { Bench Heat } \\
\text { BTU }\end{array}$ & $\begin{array}{c}\text { GH North } \\
\text { Bench Heat } \\
\text { BTU }\end{array}$ & $\begin{array}{c}\text { Culture } \\
\text { System I Heat } \\
\text { BTU }\end{array}$ & $\begin{array}{c}\text { Culture } \\
\text { System II Heat } \\
\text { BTU }\end{array}$ \\
\hline 830,000 & $22,289,000$ & $52,496,000$ & $10,696,000$ & $29,423,000$
\end{tabular}

As indicated in Figure 11, the aquaculture systems accounted for 22 percent of the total energy use during the period of February-March 1995. This amounts to a 27.4 percent increase in geothermal energy consumed by cascading to the Aquaculture Facility.

The aquaculture heating systems do not utilize all the geothermal energy available during operation of the horticultural greenhouse parent facility. Investigating the potential to increase the size of the Aquaculture Facility to achieve a greater use of the energy in the waste stream would be critical in designing a commercial system that would be cascaded onto a greenhouse range. From the analysis of heat usage for our system, the geothermal heat exchange tank used $16.4 \mathrm{gpm}$ of the available $25 \mathrm{gpm}$, but if all the available geothermal water was used, there could be a 52 percent increase in flow through the heat exchange tank. Using the current heating system configuration, the culture systems could be expanded 4 to 6 tanks. The heat exchange tank exit temperatures were high enough to allow more heat extraction without a substantial degradation in system heat transfer. It is estimated that under the existing heat transfer 
equipment configuration an additional three sets of heat coils could be added in series. This increase in coil size would still allow heat exchange tank exit temperatures to remain above $100^{\circ} \mathrm{F}$, which would provide a comfortable margin of safety for meeting cultural requirements. If these system modifications were implemented, the estimated upper limit on system size for this facility would be 24 tanks of 3,000 gallons each.

Water balance for the aquaculture system focused the months of February-March of 1995 to allow for comparison of all systems during the critical heating months of the year. The total water available for the entire geothermal complex for February and March averaged 36,200 and $37,700 \mathrm{gpd}$, respectively. Out of this value, about 23,472 gpd or 64 percent was supplied to the geothermal Aquaculture Facility for heating and culture. Culture water demand varied as shown in Figure 12 and 13 and averaged about 1,821 and 1,033 gpd for CS I and $\Pi$, respectively. CS I operated with a waste rate almost twice that of CS II due to sensitivity of Hybrid Striped Bass to poor water quality conditions. Increasing the waste rate increased the flushing of the system to maintain adequate water quality in the system. Tilapia, cultured in CS II, are much more tolerant of poor water quality and this waste rates for this system could be much lower resulting in lower water use rates.

Evaporation losses averaged about 189 and $175 \mathrm{gpd}$ for CS I and CS II, respectively. CS II had a lower loss rate than CS I despite having a higher total surface area and the presence of aquatic plants in the filter unit. Aquatic plants for waste treatment have many benefits, but they do exhibit high rates of evapotranspiration. To some degree, this can be explained by the differences in culture species behavior previously discussed. 


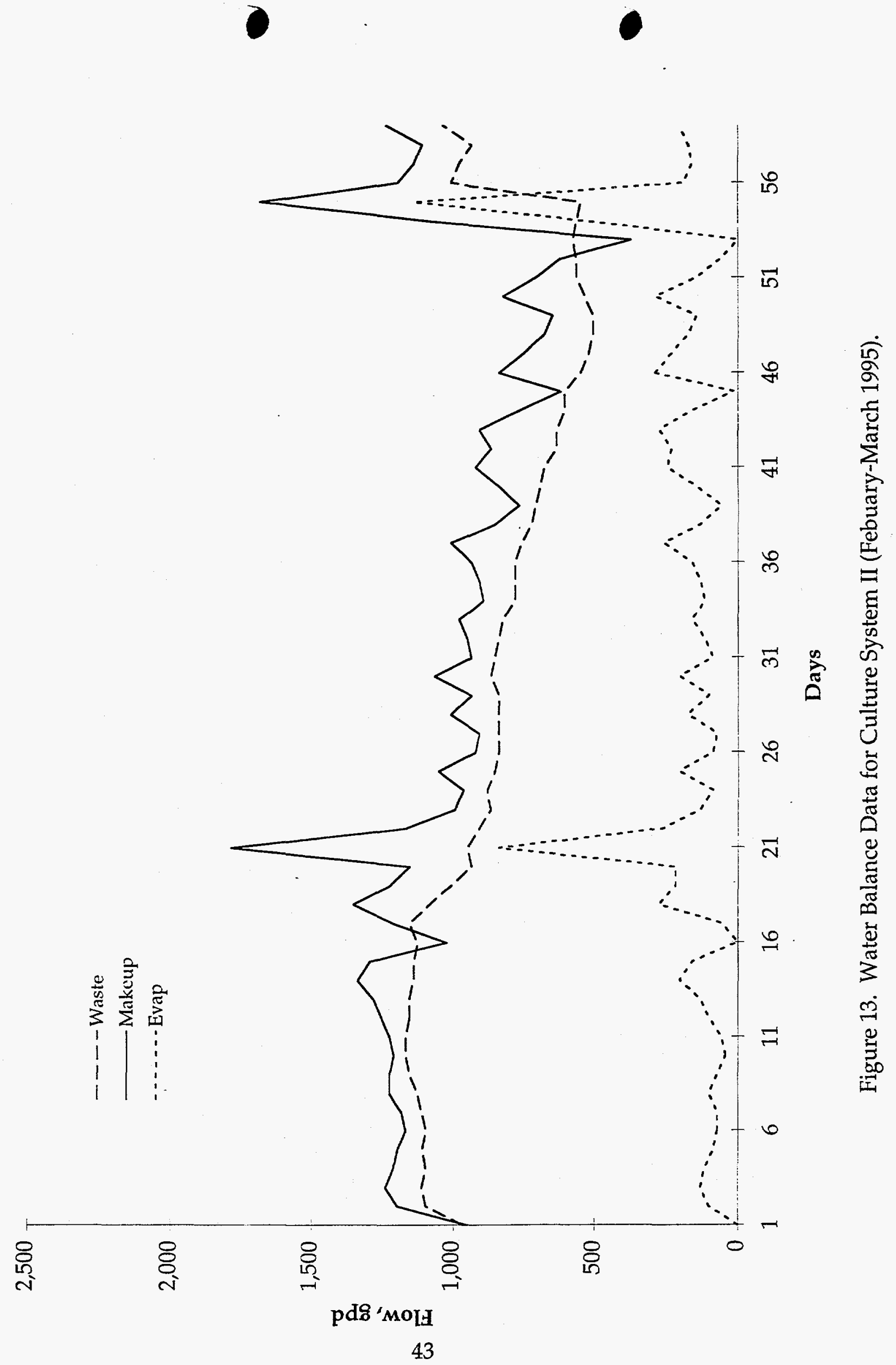


This loss from feeding behavior appeared to increase with the increasing size of the fish. In addition, some differences in water use rates can be attributed to the difference in culture water set points with higher temperatures resulting in higher evaporative losses.

The combined average water use rate for the two systems was $2,854 \mathrm{gpd}$, resulting in a culture water consumption of about 12 percent of the total geothermal water available to the facility. Optimal water use rates for the culture systems should actually approach levels somewhat higher than the rate of water lost just to evaporation or about 189 and 175 gpd for CS I and II, respectively. Actual water use rates should be about $500-1,000$ gpd or about 4 percent of the total to balance buffering capacity of the systems. Data from February and March indicated that water use rates for the two systems were very similar. Plant growth in the AWF system was very small at that time and daytime temperatures were quite low. These factors contributed to low evapotranspiration losses despite a much higher surface area for this system compared to CS I. We would expect a bigger differences between these systems in the warmer months of the year because of the higher surface area and the rapid growth and transpiration of the plants.

Based on 23,400 gpd available to the facility from their resource and water consumption for each 3,000 gallon tank of $500 \mathrm{gpd}$, about 135,000 gallons of culture tankage could be configured for this resource. 


\section{Economic Assessment}

Assuming the constraints of the heating and culture water analysis given in the previous section, the maximum culture system size for the resource at this site would be about 72,000 gallons. Cost estimates for the various system components were determined for this study. Some significant differences between this study and a commercial approach added atypical costs for things like monitoring and other data reduction activities. Thus, adjustments were made for the labor and design values. Furthermore, economics of scale would realized with larger systems. A larger system would have a smaller overall costs for brooding fingerling, and a higher cost for production and growout, however the overall cost would be lower than these presented in our system. Hatchery and production costs were not separated in this assessment, so these estimates are conservative. The adjusted values are:

$\begin{array}{ll}\$ 2.51 / \mathrm{gal} & \text { Culture System } \\ \$ 0.72 / \mathrm{gal} & \text { Greenhouse } \\ \$ 0.36 / \mathrm{gal} & \text { Control System } \\ \$ 3.70 / \mathrm{gal} & \text { Design } / \text { Labor } \\ \$ 1.21 / \mathrm{gal} & \text { Construction } \\ \$ 8.50 / \mathrm{gal} & \text { Total }\end{array}$

A culture system utilizing the existing resource and sized for about 72,000 gallons would have a total capital cost of $\$ 612,000$ for all the elements listed above. Assuming that a standing crop of $0.5 \mathrm{lb} /$ gal is produced and harvested at 5 percent per week, about $93,600 \mathrm{lbs}$ of about $1.3 \mathrm{lb}$ fish will be produced annually. Assuming a selling price of $\$ 3.00$ per $l b$, annual revenues would be about $\$ 280,000$. Annual operating costs 
(including energy, feed, and water, but excluding payoff of capital costs) were estimated to be about $\$ .30$ /gallon or about $\$ 21,600$. Salaries for operational personnel and seasonal workers are estimated to be $\$ 60,000$, resulting in total annual operating costs of $\$ 81,600$. Transportation costs would depend on the method of sale and are not factored into this estimate.

Assuming 30 percent down and an 8 percent interest rate on a loan value of $\$ 428,000$ results in annual payment of $\$ 62,400$, on a ten year loan period. Thus, the total annual costs of the culture system would be $\$ 144,000$. Estimated revenues of $\$ 280,000$ would result in a net annual profit $\$ 136,000$ for this size facility. Assuming levelized values results in a simple payback period of 4.5 years.

\section{Lessons Learned}

In the course of designing and constructing this system a number of issues were revealed that could critically affect the design and operation of future systems. Most of these were design-related issues that impact the overall concept. The heat exchanger used in the Aquaculture Facility was a site-built design using coils of polyethylene tubing spaced at regular intervals and anchored with a PVC angle frame. The coils were installed in a six-foot diameter open fiberglass tank and the hot geothermal fluid was piped into the top of the tank and drained out through the bottom of the center drain standpipe. The cool culture water was pumped through the coils for heating of the culture systems. Heating was controlled with the data acquisition and facility control computer. The weak point in this type of system is the poor heat transfer characteristics of the polyethylene tubing. It has a thermal conductivity of 3.5 
$\mathrm{BTU} / \mathrm{hr} / \mathrm{ft}^{2} /{ }^{\circ} \mathrm{F} /$ in. For adequate heat transfer this requires thinwall tubing and enough length to provide for sufficient conduction. The two sets of coils in the tank are 165 and 275 feet in length. This setup provides a heat transfer rate of $50,000 \mathrm{BTU} / \mathrm{hr}$ to the larger coil under optimal conditions. Since the fabrication and installation of this heating system, an alternative was discovered that will prove to be less expensive and more effective. One of our regular aquaculture vendors now stocks a stainless steel heat exchange coil that can be submerged in a tank of hot fluid just as is currently done at the facility. The conductivity of the stainless steel coil is $250 \mathrm{BTU} / \mathrm{hr} / \mathrm{ft}^{2} /{ }^{\circ} \mathrm{F} / \mathrm{in}$. This is more than 70 times more effective than the polyethylene coil. This enables the use of a small prefabricated coil which saves a considerable amount of labor in a heat exchanger installation. This stainless steel coil is available in two sizes, one with a $40,000 \mathrm{BTU} / \mathrm{hr}$ output and one with an $75,000 \mathrm{BTU} / \mathrm{hr}$ output. The price of these coils is very competitive, less than the materials cost of the polyethylene coil heating system, plus there is a large savings in labor. We currently have one heating system on line with a stainless steel coil for use with the facility brood and fry tanks. It has performed well in heating these tanks.

The aquaculture greenhouse environment has proven to be quite hard on certain types of equipment. During periods of cool weather, from November through February, the greenhouse is closed up for relatively long periods overnight. This creates a situation where the relative humidity climbs to 100 percent and it rains in the greenhouse from the excess moisture given off by the warm culture tanks. These periods of 100 percent humidity adversely affect many materials in the structure. Rusting is a problem with unprotected iron and steel. We have experienced problems 
with controllers in the environment such as solid state thermostats. When the thermostats were moved into the facility control room which is provided with a supply of dry air from outside the problems ceased. Corrosion of pumps and metal solenoid valves is a continuing problem. The most effective way to overcome these problems is by moving delicate equipment into a safe environment and by selecting materials that are not affected by these high humidity levels.

A significant advantage of separating these units allows the optimization of the input solar gain to maximize culture water temperatures. Separation of the environments would allow temperatures inside the greenhouse to rise well above $95^{\circ} \mathrm{F}$ with humidity approaching saturation. This would tend to reduce evaporation rates and maintain higher temperatures in the systems. The environment could be rapidly exhausted or cooled when it was necessary for entry or during summer time operation. Obviously proper control under the rapidly changing scenarios for solar heating would require computer control to avoid over heating.

A major consideration for site configurations is the location of an elevated geothermal cooling pond to provide culture makeup water by gravity flow. A cooling pond is necessary to lower the temperature of the makeup water so as not to run the culture systems at elevated temperatures during warm weather. Where feasible, gravity flow is preferable due to its simplicity and reliability. One of the most important lessons to be learned from working with intensive culture systems is to keep the facility design as simple as possible. Mechanical equipment of all kinds is subject to breakdowns and other problems. The fewer components that a system has, the more reliable it becomes. 
A geothermally-heated aquaculture facility should be designed to utilize an indirect heating system that can provide heat at a low but steady rate. This enables room for operator error or equipment malfunction without quickly leading to a catastrophic deterioration of the culture environment. Direct geothermal heating provides a quick and dirty solution to the problem of heating but it can lead to disastrous consequences when the control equipment fails. The high temperature water can quickly produce uninhabitable temperatures within the culture tank. An indirect heating system that can operate in a full on status for hours without reaching dangerous temperatures is preferable from the operational standpoint because sooner or later one can expect an equipment or controller failure. This increased time frame allows for operator intervention to correct the problem. The large thermal mass of aquaculture systems is an advantage for the operator because it gives him more time to discover and correct heating system failures.

\section{Summary}

A demonstration high rate aquaculture production system utilizing a cascaded geothermal resource was designed, constructed and operated to fulfill the objectives of this project. Analysis of the energy and water balances for the system indicated that the addition of an Aquaculture Facility expanded the use of the existing resource. This expanded use in no way affected the up-stream processes. Analysis of the system's energy and water requirements indicated that the present resource was under-utilized and could be expanded. Energy requirements appeared more limiting than water use, but the existing system could be expanded to a culture volume of 72,000 gallons. This 
system would have a potential production capacity of $93,600 \mathrm{lbs} /$ year with a potential market value of $\$ 280,000 /$ year.

Based on the results of this study, the heat remaining in the geothermal fluid from one square foot of operating greenhouse is sufficient to support six gallons of culture water for a high density aquaculture facility. Thus, the over 1.5 million $\mathrm{ft}^{2}$ of existing greenhouse space in New Mexico, has the potential to create an aquaculture industry of nearly nine million gallons. This translates to an annual production potential of 11.7 million pounds with a market value of $\$ 35.1$ million. 


\section{References}

ATA, American Tilapia Association, Situation and Outlook Report 1995.

Balm, R. J. et al., "New Mexico Climate Manual: Solar and Weather Data," NMERDI Report No. 72-4523, 1985.

Bin, -C.; Zhitang, -D.; and Ju, -P. J. Engineering in Relation to Heating the Plastic Greenhouse by Geothermal Energy for Raising Grafted Flower and Fruit Tree. Transact. of Chinese Soc. Agriculture Mach., Bejing, China, 1988.

Bovedeur, J.; Zwaga, A. B.; Lobee, B. G. J.; and Blom, J. H. Fixed film reactors in aquacultural water recycle systems: effect of organic matter elimination on nitrification kinetics. Wat. Res. Vol 24 No. 2 pp 207, 1990.

Boyle, W. A.; Seawright, D. E.; Neilsen, R. E.; Bledsoe, G. E.; and Pigott, G. M. Model Preliminary Engineering Study for a Tilapia Aquaculture Facility Using Geothermal Water. Proceedings of an Aquacultural Engineering Conference, Spokane, WA, June 2123, 1993.

Brannon, J., "Trout-An Industry on the Move," Seafood Leader Buyer's Guide, Vol. 7, No. 1, 1987.

Cheyne, S. Geothermal Aquaculture: a pilot project for intensive culture of the mosquito fish, Gambusia affinis, for biological mosquito control. Proceedings of the Annual Conference California Mosquito and Vector Control Association, Sacramento, CA, 1982.

Gersberg, R. J.; Elkins, B. V.; Lyons, S. R.; and Goldman, C. R.; Role of aquatic plants in wastewater treatment by artificial wetlands. Water Res. 20, 363-368, 1986.

Hayes, A. and Johnson, W. Geothermal Aquaculture: Guide to Freshwater Prawn Culture, Oregon Institute of Technology, Geo-Heat Utilization Center , Klamath Falls, OR, 1986.

Lansford, R. et al., "Evaluation of Available Saline Water Resources in New Mexico for the Production of Microalgae," SERI Report No. ZK-50091-1, 1986.

Malone, R. F.; Chitta, B. S.; and Drennon, D. G. Optimizing Nitrification in Bead Filters for Warmwater Recirculating Aquaculture Systems. Proceedings of an Aquacultural Engineering Conference, Spokane, WA, June 21-23, 1993.

Schoenmackers, R., "Geothermal Heating of Greenhouses in the Southwestern United States," International Seminar on Greenhouse Technology, Tel-Aviv, Israel, March 27-28, 1990. 
Smith, K. Direct Utilization of Geothermal Heat in Cascade Application to Aquaculture and Greenhouse Systems at Navarro College, Department of Energy Report, DOE/ET/27058-1, 1984.

Patterson, T. Hatchery Training Program, College of Southern Idaho, Personal Communication, 1992.

Popovski, K. Present Status and New Area for Investigation of Thermal Effluents for Heating Greenhouses. International Society for Horticulture Science, V 245, pp 158-164, 1989.

Rackocy, J. E. and Hargreaves, J. A. Integration of Vegetable Hydroponics with Fish Culture: A Review. Proceedings of an Aquacultural Engineering Conference, Spokane, WA, June 21-23, 1993.

United States Department of Agriculture. Aquaculture: Situation and Outlook Report. AQUA-11 September 1993.

Weissman, J., Personal Communication, 1992.

Winfree, R. A., "Tropical Fish - Their Production and Marketing in the United States," World Aquaculture, Vol. 20 (3), pp 24-30, 1989.

WRAC, "Waterlines Newsletter of the Western Regional Aquaculture Consortium, Arizona One+One = Three," Winter 1989.

Zachritz II, W. H. and Jacquez, R. B. "Treating Intensive Aquaculture Recycle Water Using Artificial Wetlands Filters," In: Constructed Wetlands for Water Quality Improvement, G. A. Moshiri (Ed), Lewis Publishers, Chelsea, MI, 1993.

Zachritz II, W. H.; Polka, R. L.; and Schoenmackers, R. "Potential for Intensive Aquaculture Production Cascaded from Geothermal Greenhouse Operations." Geothermal Resources Conference October 1991, Reno, NV, 1991.

Zachritz II, W. H.; Fischer, C. L.; Foster, R.; Turietta, M. H.; Whittier, J. R.; and Witcher, J. C. New Mexico Economic Development and Geothermal Resources: Potential Industry Applications. Report Submitted to New Mexico Energy, Minerals, and Natural Resources Department, Santa Fe, NM, 1989.

Zachritz II, W. H.; Polka, R. L.; and Berghage R.D. Design Development of an Artificial Wetlands Filter Systems for Geothermal-Based High -Density Tilapia Culture Systems. Presented at the World Aquaculture Society Meeting, San Diego, CA, 1995. 
